\title{
DE BURGOS A EL PUERTO DE SANTA MARÍA. EL FUTURO PROFESIONAL DE LA NOBLEZA DE PROVINCIAS. LOS MARQUESES DE LORCA EN EL SETECIENTOS
}

\author{
Francisco José Sanz de la Higuera \\ I.E.S. "Torreblanca" (sevilla)
}

\begin{abstract}
RESUMEN
El futuro profesional de los segundones de una familia noble residente en una provincia marginal y periférica, el Burgos de mediados del Setecientos, se canaliza a través de la compra de empleos militares en un regimiento acantonado en El Puerto de Santa María (Cádiz). De una forma inusitada, asistimos a la almoneda de una capitanía y una tenencia en la que el sonido del dinero transforma la molicie civil en lenidad castrense. El negocio de las patentes enriquecía a unos pocos, los intermediarios, y saqueaba los bolsillos de las familias aristocráticas.
\end{abstract}

Palabras clave: futuro profesional, segundones, empleos militares, siglo XVIII, patentes.

\section{ABSTRACT}

The professional future of the "segundones" of a noble family resident in a deprived and peripheral province, Burgos in the middle of the $18^{\text {th }}$ Century, is achieved by means of the purchase of military jobs in a regiment stationed in El Puerto de Santa María (Cádiz). In an unusual way, we attend the clearance sale of a captaincy and a tenancy in which the sound of the money transforms the civil complacency into military comforts. The business of the patentes enriched a few, the intermediaries, and sacked the pockets of the aristocratic families.

Key words: professional future, segundones, military jobs, $18^{\text {th }}$ Century, patentes. 


\section{Introducción y fuentes documentales}

El Marqués de Lorca no tenía pelos en la lengua -como demostró en múltiples ocasiones ${ }^{1}$ - al situarse, entre angustiado y esperanzado, ante el futuro profesional, y humano, de sus hermanos menores. Los segundones de su familia, de su hogar burgalés, se encontraban ante la disyuntiva de resolver, de la mejor y más productiva manera, cuáles serían los parámetros esenciales de su porvenir, que no pasaban por languidecer a la sombra del mayorazgo parental ${ }^{2}$. En aras de encauzar el devenir laboral de su dilatada familia, don Gaspar de Castro, Gutiérrez y Cárdenas, III Marqués de Lorca, ${ }^{3}$ “...deseando dar carrera conforme a su ilustre calidad y inclinándose a imitación de sus antecesores a servir a $S$. $M$. en el ejercicio de las armas..." ", rubricó un documento que constituye, a mi modesto entender, un hecho inusitado y sin precedentes de compra-venta de "patentes" militares ${ }^{5}$. La "réthorique du lignage et [la] mémoire généalogique" eran meros cortinajes barrocos interpuestos para ocultar la pura y simple realidad. La economía del hogar, y más en el de un recién casado, no podía soportar por mucho tiempo la presencia de "intrusos", aunque éstos sean sus hermanos menores. El marqués de Lorca, al airear públicamente sus tratos con don Manuel Dongo, quebraba el pacto de imprescindible silencio, de discreción clandestina, que tales operaciones de venalidad castrense demandaban ${ }^{6}$.

La búsqueda de documentación sobre las vicisitudes del hogar de los Castro ha generado la aparición de múltiples informaciones de suculenta utilidad para conocer su devenir e idiosincrasia. En primera instancia, descuella, merced a un rastreo intensivo - de tercera generación ${ }^{7}$ - en los protocolos notariales, la disponibilidad de la citada "Escritura de ventta rreal y perpetua enagenación" para sus

\footnotetext{
1 Las actitudes tensas y el carácter fuerte y proclive a la brusquedad y a la descalificación del III marqués de Lorca han sido analizados en BALLESTEROS CABALLERO, Floriano: La sociedad Económica de Amigos del País de Burgos, Burgos, 1983, pp. 21, 74-75 y 80-82 y SANZ DE LA HIGUERA, Francisco José: ““'Estando como estamos juntos y congregados en la Casa de dha Contratación como lo acostumbramos". Luces y sombras en el Consulado de Burgos", Boletín de la Institución Fernán González, 229, (2004), pp. 377-413.

En el tratamiento de los segundones descuellan, entre otras obras, BARRERA GONZÁLEZ, Andrés: Casa, herencia y familia en la Cataluña rural (Lógica de la razón doméstica), Madrid, 1990, BARRERA GONZÁLEZ, Andrés: "Unigenitura y familia troncal", Los Pirineos. Estudios de antropología social e historia, Madrid, (1987), pp. 177-215, BARRERA GONZÁLEZ, Andrés: "Sucesión unipersonal y familia troncal en la "Catalunya Vella", Revista de Antropología Social, 0, (1991), pp. 179-204, FERRER i ALÓS, Llorenç: "Segundones y actividad económica en Cataluña (siglos XVIII-XIX). Reflexiones a partir de la familia Berenguer de Artés", Revista de Demografía Histórica, 21/2, (2003), pp. 93-128 y REY CASTELAO, Ofelia: “¿Bienestar o supervivencia? Herederos en el Noroeste español, siglos XVIII-XIX", Symposium The Transmisión of Well-Being: Marriage Strategies and Inheritance System in Europe (17th-20th Centuries), Guimaraes, 2007.

3 Véase ribetes de su biografía en LOPEZ GÓMEZ, José Manuel: "Razón y locura en el Burgos de la Ilustración. El caso del Marqués de Lorca”, Estudios de Historia y Arte. Homenaje al profesor D. Alberto C. Ibáñez Pérez, Burgos, 2005, pp. 177-181 y SANZ DE LA HIGUERA, Francisco José: "Aproximación a la locura en el Setecientos burgalés. Cerebros, humores y economía en desequilibrio", Investigaciones Históricas, 29, (2009), (en prensa).

Archivo Histórico Provincial de Burgos. Protocolos Notariales (en lo sucesivo AHPB. PN). Francisco de Villafranca. Legajo 7097 (31 de enero de 1766), folios 15-17.

ANDUJAR CASTILLO, Francisco: El sonido del dinero. Monarquía, ejército y venalidad en la España del siglo XVIII, Madrid, 2004, REYES GARCÍA-HURTADO, Manuel: El arma de la palabra. Los militares españoles y la cultura escrita en el siglo XVIII (1700-1808), La Coruña, 2002, GORAU, François: La venalité des charges militaires en France au XVIIe et XVIIIe siécles, Villeneuve d'Asq, 2002, GIBIAT, Samuel: "Un corps d'officiers d'administration entre venalité des charges et militarisation, ou le dilemme des commisaires des guerres à l'époque Moderne", Cahiers d'études d'histoire de la Défense, 19, (2002), pp. 11-36 y ARAGÓN MATEO, Santiago: La nobleza extremeña en el siglo XVIII, Mérida, 1990, pp. 447-476.

6 ANDUJAR CASTILLO, Francisco.: Op. Cit., pp. 18-22. "“Que no suene el dinero”. Tal fue la consigna repetida por algunos compradores de empleos militares cuando promocionaron en el escalafón o ingresaron en la carrera de las armas desde grados como los de capitán o coronel" (pp. 18). "La literatura militar del siglo XVIII silenció cualquier referencia a la práctica de la compra de empleos militares" (pp. 19). Las excelentes palabras del profesor Andujar resultan, a este respecto - y el marqués de Lorca lo sabía y lo practicaba abiertamente -, premonitorias: "Entre tantos silencios y ocultaciones, la única posibilidad del historiador es "cruzar" el mayor número posible de fuentes documentales, para mostrar, primero, la historia, y, después, desvelar el "veneno" que impregna buena parte de los documentos que yacen en los anaqueles de los archivos" (pp. 22).

Véase CHAUNU, Pierre: “Un nouveau champ pour l'histoire sérielle: le quantitative au troisième niveau", Méthodologie de l'histoire et des sciencies humaines, París,1978, pp. 216-217 y GONZÁLEZ CRUZ, David: Religiosidad y ritual de la muerte en la Huelva del siglo de la Ilustración, Huelva, 1993, pp. 22-23.
} 
hermanos ociosos ${ }^{8}$. Se ocupó también de encauzar el futuro profesional de don Pedro, el benjamín de sus hermanos ${ }^{9}$. Del AHPB proceden igualmente piezas esenciales de sus existencias ${ }^{10}$.

El Catastro de Ensenada posibilita un conocimiento pormenorizado del hogar de los Lorca a mediados del Setecientos (1751), en especial del tamaño y estructura del continente en que vivían, la casa, y del contenido, es decir, de los componentes de la familia ${ }^{11}$. En el Archivo Municipal de Burgos se encuentran custodiadas las Comprobaciones de Catastro $(1761)^{12}$ y un excelente y detallado Vecindario $(1778)^{13}$ que, conjugados unos con otros, permiten efectuar un análisis de los ciclos vitales de los hogares de los Castro Gutiérrez. Los Sacramentales de las parroquias burgalesas, en especial los libros de matrimonios, bautismos y defunciones de San Lorenzo - de la que eran "Parroquianos"14-, nos acercan al fluir de la llegada y la marcha de sus integrantes y a su participación en el mercado nupcial. Otros aspectos complementarios de los quehaceres y conducta de don Gaspar proceden del Archivo Histórico Nacional ${ }^{15}$, del Archivo de la Diputación Provincial de Burgos ${ }^{16}$ y de la bibliografía publicada sobre su persona ha conocido la luz hasta el momento presente ${ }^{17}$.

\section{Ansiedad ante el futuro de los segundones en la nobleza burgalesa de mediados del siglo}

\section{XVIII}

Si ya era difícil para un padre urdir las trayectorias de futuro de sus hijos e hijas, el reto al que se enfrentó don Gaspar de Castro, III Marqués de Lorca, desde que recibió las responsabilidades de curador y tutor de sus hermanos menores, en $1763^{18}$, era notable y espinoso. Su corta edad, el no estar quizá preparado ni predispuesto para ello y el enorme cúmulo de problemas que la gestión de sus intereses suponía supusieron una ingente cantidad de exigencias y esfuerzos. Él era, como primogénito vivo ${ }^{19}$, el heredero universal de gran parte de la fortuna de su padre, de la titularidad de los mayorazgos de la familia y de la responsabilidad de mantener y dar estado a sus hermanos. Tales circunstancias situaban

8 Los implicados fueron don Gaspar, sus hermanos, don Francisco y don Antonio, y don Manuel Dongo. AHPB. PN. Francisco de Villafranca. Legajo 7097 (31 de enero de 1766), folios 15-17.

9 Para quien gestionó el acceso a una "plaza en el Real Colegio Militar de Caballeros Cadetes del Real Cuerpo de artilleros". AHPB. PN. Francisco de Villafranca. Legajo 7097 (26 de agosto de 1766), folios 190-195. Sabemos por la Revista Hidalguía que Ramón de Castro Gutiérrez alcanzó el grado de mariscal de campo en 1808. Su Expediente Personal, custodiado en el Archivo General Militar de Segovia, es citado en Hidalguía, tomo II (BÓ-CHY), (1990), Madrid, pp. 306.

10 Capitulaciones matrimoniales, cartas de arras, testamentos, inventarios post-mortem, curación y tutoría de hermanos y sobrinos, poderes para la gestión y administración de sus intereses económicos, escrituras de cesión de los frutos de los mayorazgos.

${ }^{11}$ Archivo de la Diputación Provincial de Burgos. Catastro de Ensenada (en adelante ADPB. CE). Respuestas Particulares. Seglares. Libro 344, folios 943-949.

12 Archivo Municipal de Burgos (AMB). Histórica. Legajo 2-8-4 (1761).

13 AMB. Histórica. Legajo 12-239 (1779).

14 Tal declaración consta en sus testamentos y se verifica su certeza a través de los Sacramentales de dicha parroquia. AHPP. PN. Diego Fernández Cormenzana. Legajo 7082 (6 de septiembre de 1755), folios 123-128 e Ibídem. Francisco de Villafranca. Legajo 7095 (2 de febrero de 1763), folios 262-265. Los Sacramentales en Archivo Diocesano de Burgos (ADB). Libros de bautismos, defunciones y matrimonios de San Lorenzo.

15 AHN. Consejos Suprimidos. Legajo 923/6 (1780-1785). Junta Particular de Gobierno del Consulado de Burgos.

16 ADPB. Fondos del Consulado. Se señalarán oportunamente en el momento idóneo.

17 BALLESTEROS CABALLERO, Floriano: op. cit., 1983, LÓPEZ GÓMEZ, José Manuel: op. cit. , 2005 y SANZ DE LA HIGUERA, Francisco: "Las restauraciones del Consulado de Burgos", Historia, Instituciones, Documentos, 29, (2002), pp. 429-458, ““Estando como estamos...”, Boletín de la Institución Fernán González, 229, (2004), pp. 377-413 y "Aproximación a la locura en el Setecientos burgalés", Investigaciones Históricas, 29, (2009), (en prensa).

18 AHPB. PN. Francisco de Villafranca. Legajo 7095 (26 de mayo de 1763), folios 637-640, Ibídem (12 de octubre de 1763), folios 633-636), Ibídem (18 de noviembre de 1763), s/f e Ibídem (13 de octubre de 1764), folios 647-649.

19 El primogénito salido de las entrañas de su madre, doña Josefa Gutiérrez y Salamanca, fue Manuel Esteban Gaspar, nacido el 24 de diciembre de 1739, entre las 7 y las 8 de la mañana, bautizado en San Lorenzo el 28 de diciembre y fallecido el 7 de octubre de 1760. ADB. San Lorenzo. Libro de bautismos. Legajo 1, folio 237-238. ADB. Nuestra Señora de Viejarrúa. Libro de difuntos. Legajo 1, folios 111-112. A él se refiere su padre, don Francisco Antonio, cuando en sus últimas voluntades declara "ser mi hijo mayor (...) Dn Manuel Estevan Gaspar de Castro, la Torre y Cárdenas, y como tal, desde mi fallecimiento, es lejítimo subzesor de todos los vínculos y Mayorazgos que al presente gozo y poseo y me pertenecen en esta Ciudad, sus zercanías y patronatos, como de el Mayorazgo situado en la Villa de Archidona, Reyno de Granada". La enumeración de sus "universales herederos" no deja lugar a duda del puesto de cada uno de ellos: "Dn Manuel Estevan, $D^{a}$ María Lucía, D María Vizenta, Dn Gaspar, Dn Francisco, Dn Antonio, Dn Ramón y Dn Pedro (...) mis ocho hijos legítimos". AHPB. PN. Diego Fernández de Cormenzana. Legajo 7082 (6 de septiembre de 1755), folios $123-128$. 
a los demás, es decir, a don Francisco ${ }^{20}$, don Antonio ${ }^{21}$ don Ramón ${ }^{22}$ y don Pedro $^{23}$, en una situación complicada por su calidad de segundones, sujetos a su autoridad y a sus decisiones. No era ya sólo un problema de espacio físico ${ }^{24}$ sino, sobre todo, de contabilidad doméstica ${ }^{25}$.

La anotación puntual y pormenorizada de los gastos que don Gaspar efectuó a lo largo de los años que compartieron vida cotidiana en el edificio de la calle San Lorenzo no ha llegado hasta nosotros ${ }^{26}$. Me serviré, no obstante, de un expediente notarial en el que estuvo implicado también don Gaspar para evaluar, aunque de manera indirecta, el coste de la tutoría de sus hermanos. "La quenta general de las rentas y efectos producidos de sus vienes libres y maiorazgos, de todo el tiempo que ha sido tal curador" ${ }^{27}$, ilustra, de una forma excelente, la estancia de su sobrino don Joaquín Santiago de Vega y Castro, hijo de su hermana doña María Lucía ${ }^{28}$, en el seno de su hogar entre 1772 y $1783^{29}$.

En don Joaquín, el III marqués de Lorca, su tío don Gaspar, invirtió, en total, 22.000 reales $^{30}$. En concreto, en vestuario y calzado se desembolsaron 5.929 reales (1775-1783), a razón de 659 reales/

20 ADB. San Lorenzo. Libro de bautismos. Legajo 1, folio 302. Don Francisco de Paula nació el 31 de marzo de 1748 y fue bautizado el 2 de abril. Falleció, como recalcaremos más adelante, el 29 de octubre de 1769, a los 21 años de edad, siendo capitán del Regimiento de La Princesa. Véase AHPB. PN. Julián Álvarez. Legajo 7264 (1 de junio de 1774), folios 146-147.

${ }^{21}$ ADB. San Lorenzo. Libro de bautismos. Legajo 1, folio 319. Don Antonio Lesmes nació el 30 de enero de 1751, entre las 7 y las 8 de la noche y recibió las aguas bautismales el $1^{\circ}$ de febrero. Falleció, a los 22 años, en sus quehaceres de teniente del susodicho Regimiento de La Princesa.

22 ADB. San Lorenzo. Libro de bautismos. Legajo 1, folio 329. Don Ramón nació el 23 de mayo de 1752, entre las 6 y las 7 de la mañana y fue bautizado el 24 de mayo.

23 ADB. San Lorenzo. Libro de bautismos. Legajo 1, folio 333-334. Don Pedro nació el 1 de julio de 1753 y fue bautizado el 2 de ese mismo mes.

24 La casa en la que se albergaba el hogar de los marqueses de Lorca, sita en la calle San Lorenzo, era propiedad de don Fernando de Salamanca, suegro de don Gaspar. Se pagaban de alquiler 700 reales/año. Se trataba de una hermosa edificación que disponía de 320 $1 / 2 \mathrm{~m}^{2}$ de planta y 16.8 metros de altura, los cuales permitían la existencia de 3 espacios habitables, a parte los desvanes. El hogar de los Castro y Cárdenas disponía de aproximadamente $961 \mathrm{~m}^{2}$ para la corresidencia. Si consideramos la presencia del matrimonio principal, don Gaspar y doña Manuela, los 4 hermanos en cuestión, un criado y su cónyuge, también parte del servicio doméstico, una criada más y el cochero, es decir, 10 individuos, obtenemos un promedio de $96 \mathrm{~m}^{2}$ por persona. En casa de don Francisco Antonio, su padre, II marqués de Lorca, siendo como eran 17 en la vivienda, el espacio fue menor, $56 \mathrm{~m}^{2}$. ADPB. CM. Respuestas Particulares. Seglares. Libro 344, folios 943-949.

25 Había que mantener, vestir y educar a unas personas, sus hermanos menores, y era imprescindible llevarlo a cabo con el decoro, la salubridad y un acierto incuestionable para que no se truncara su porvenir y abandonaran, no obstante, el nicho familiar con prontitud. ¿Qué era lo más adecuado y funcional en tales empeños? ¿Qué mecanismos era preciso tocar y en dónde para canalizar sin excesivos traumas ni sinsabores su devenir profesional y humano?

26 O, al menos, yo la desconozco o no he sido capaz de encontrarla.

27 AHPB. PN. Alonso de Melo Peña. Legajo 7219 (11 de agosto de 1784), folios 284-296. El nombramiento como tutor en AHPB. PN. Julián Álvarez. Legajo 7264 (29 de julio de 1776), folio 403. Doña María Lucía otorgó testamento en Villafranca del Bierzo el 30 de abril de 1772, documento en el que se encargó la "tutela y Curaduría de dn Joaquín". Véase IMíZCOZ BEUNZA, José María (Dir.): Redes familiares y patronazgo. Aproximación al entramado social del País Vasco y Navarra en el Antiguo Régimen (siglos $X V$-XIX), Bilbao, 2001, HERNÁNDEZ FRANCO, Juan y PEÑAFIEL RAMÓN, Antonio: "Parentesco, linaje y mayorazgo en una ciudad mediterránea: Murcia (siglos XV-XVIII), Hispania, 198, (1998), pp. 157-183 y GROPPI, Angela: "Il diritto dei sangue. La responsabilitá familiari nei confronti delle vecchie e delle nouve generazioni (Roma, secoli XVIII-XIX), Quaderni Storici, 92, (1996), pp. 305-333.

28 ADB. San Lorenzo. Libro de bautismos. Legajo 1, folio 245-246. Doña Lucía Concepción nació el 13 de diciembre de 1740, entre las 9 y las 10 de la mañana. En 1763, en el momento en que se redacta el último testamente de su padre, ya había contraído matrimonio con don Juan Manuel de la Vega, vecino de Villafranca del Bierzo. En las últimas voluntades de 1755 aún estaba soltera. AHPB. PN. Diego Fernández de Cormenzana. Legajo 7082 (6 de septiembre de 1755), folios 123-128 e Ibídem. Francisco de Villafranca. Legajo 7095 (2 de febrero de 1763), folios 262-265.

29 No es aceptable, evidentemente, efectuar un traslado directo y equivalente de los capítulos de gasto invertidos en una sola persona al derramado en 4 ó 5 hermanos pero si nos da una idea aproximada del perfil que adoptaría la contabilidad del marqués de Lorca ante la difícil tarea de sostener, con la calidad nobiliar exigible, la existencia de su hogar y la corresidencia con sus hermanos.

30 AHPB. PN. Alonso de Melo Peña. Legajo 7219 (11 de agosto de 1784), folio 295. "en los once años desde noviembre de setenta y dos hasta febrero deel presente de ochenta y quatro, y a razón de dos mil y doscientos en cada uno, [que] importan los alimentos prestados a dho dn Joaquin, pues aunque con respecto a sus circunstancias, criados para su servicio, propinas de Peluquero durante dho tpo, partidas que le ha dado para jugar, sus gastos extraordinarios y compra de cosas y enredos que se le an ofrecido, se le devía exijir mayor contribución, no tiene por Conveniente el Sr Marqués Cargarle más que la que va expresada, por el amor que le tiene, no obstante que su Madre y Padrastro le Cargaron aún en el tpo de su lactancia al respecto de dhos Doscientos Ducados al año por razón de alimentos y además el salario del Ama, criados u ropas para su uso". 
año ${ }^{31}$. En educación, se consumieron 4.820 reales - a 535 1 $\frac{1}{2}$ reales/año- ${ }^{32}$. De gastos varios se anotaron partidas por un total de 12.823 reales. Descuellan las partidas efectuadas para la administración de sus propiedades, la burocracia de la curación y los viajes y obsequios de don Joaquín ${ }^{33}$. En resumen, la crianza del sobrino supuso invertir aproximadamente 4.000 reales al año. Don Joaquín fue mutando sus perspectivas desde una supuesta vocación castrense -se anotaron 145 reales "que costó la conduzion y composición del Arcón forrado en Yerro que se trajo de Villafranca cargado de ropa blanca con el objeto de hacer menos dispendiosa la salida que el dn Joaquín deseava por entonces al exerzito" ${ }^{34}$ - hasta la realización de su boda ${ }^{35}$. El sobrino generó un "Alcance" en su contra de 26.146 1 1/2 reales ${ }^{36}$.

Si damos por aceptable que en don Joaquín se gastó, de promedio, 4.000 reales al año, ello significa que en sus hermanos don Francisco, don Antonio y don Pedro el marqués de Lorca invirtió 12.000 reales/año, cantidad que mermaría de manera notable sus disponibilidades financieras y, sobre todo, su paciencia y la de su joven cónyuge. Ni pensar, ni por un instante, en casarlos ${ }^{37}$.

La conflictividad familiar en sus múltiples facetas era un conjunto de circunstancias que atravesaba, con mayor o menor severidad, el interior de gran parte de los hogares ${ }^{38}$. Las exigencias de unos adolescentes pueden estar preñadas de mucha violencia y de estridencias desagradables que ponen a padres, madres, hermanos, hermanas, tíos y sobrinos al borde de la desesperación y la angustia. Invertir

31 Ibídem, folios 289-291. Este capítulo de gasto era bastante más voluminoso pero "Previénese no se carga cosa alguna por razón de Zapatos, medias de lana y seda y sombreros, Camisolas, ropas blancas, Vestidos, hechuras y demás ropas sacadas para dho dn Joaquín desde el año de mil Setecientos setenta y dos en que vino a esta Ciudad hasta fin de Diciembre de Setenta y quatro, por no haver llevado en este tpo que estuvo ausente el Sr Marqués quenta ni razón alguna mi Señora la Marquesa, ni tampoco por las ropas y otras alajas que dho Marqués le ha traído en las Ocasiones que se ha allado en la Corte, Pamplona, francia, Santander y otros Puertos". Y, además, "No se le Carga Cosa alguna por las Camisas, Camisolas, bueltas para ellas, Calzoncillos, Justillos, Calzetas, Corbatines, medias de lana y seda, pañuelos y otras Cosas desde dho año de Setenta y dos hasta el pasado de ochenta y tres en que se trató de Casar, por no haver llevado en esta parte quenta ni razón alguna dho Señor Marqués".

32 Ibídem, folio 289. “... en su educación, esto es, en Maestros de primeras letras, Latinidad, Geografía, Lengua francesa, Bayle, florete y Música, en esta forma. A los Maestros de primeras letras, Nogates y Vizcaya, por todo el tpo que le enseñaron a leer, Escribir y contar, novecientos rrs; Al de latinidad, mil y doscientos; al de Geografía y Lengua francesa, por quatro meses de enseñanza a razón de ocho pesos Cada uno, quatrocientos y Ochenta rrs; Al de florete, Maestro Escafain y Francisco el Italiano, por siete meses de enseñanza, trescientos y veinte rrs; Al de Vayle, ciento y ochenta rrs; al de Violín, por dos años de Lección, a razón de quatro pesos al mes, mill quattrocientos y quarenta rrs y por los libros, cuerdas, papeles de Música, floretes y otras Cosas trescientos rrs, como todo por menor resulta del libro de apuntaciones que tiene y ha llevado dho Señor Marqués". Cfr., entre otros, GONZÁLEZ CRUZ, David: Familia y educación en la Huelva del siglo XVIII, Huelva, 1996,VIÑAO FRAGO, Antonio: "Los estudios de latinidad y gramática en la España del Antiguo Régimen", Historia y educación en Murcia, Murcia, 1983 y "La historia de la alfabetización a través de las fuentes notariales. Aportaciones provisionales sobre el proceso de alfabetización en Murcia (1760-1860)", Aproximación a la investigación histórica a través de la documentación notarial. Cuadernos del Seminario "Floridablanca”, 1, (1985), pp. 33-55, ANTÓN PELAYO, Javier: La herencia cultural. Alfabetización y lectura en la ciudad de Girona (1747-1807), Barcelona.

33 AHPB. PN. Alonso de Melo Peña. Legajo 7219 (11 de agosto de 1784), folios 287-289 y 291-293.

34 AHPB. PN. Alonso de Melo Peña. Legajo 7219 (11 de agosto de 1784), folio 292.

35 Ibídem, folios 292-295. "Gastos de Boda y otros Ocasionados por este mottivo, suplidos por el Señor Marqués". El enlace supuso una derrama de 54.188 reales, es decir, el 35.8 \% de los gastos generados por don Joaquín. Descuella, entre otros, una "Sortija de Brillantes", con un desembolso de 2.700 reales, es decir, 45 doblones, "que se compró en la Casa y lonja de don Santiago Menino, vecino y Comerciante en Madrid para que dho dn Joaquin la regalase a Zierta Señorita, y por no haver tomado Efecto sirvió para regalar a su Esposa actual". Destaco este aserto para poner en evidencia el tremendo grado de derroche y de indecisión en que se movían los vástagos de la aristocracia, fenómenos que desfondaban las arcas familiares e hipotecaban sus futuros.

36 Lo recaudado ("Cargo") fue 124.803 1/2 reales y lo gastado ("Data") 150.950 reales

37 Don Gaspar tendría aún grabado a fuego en su memoria la "Manda dottal a Da María Vizenta de Castro", 154.000 reales, que su padre, don Francisco Antonio, efectuó para casar a la hija con don Diego María de Salamanca, hermano de doña Manuela, su cónyuge. AHPB. PN. Francisco de Villafranca. Legajo 7095 (30 de agosto de 1763), folio 585. Doña María Vicenta fue bautizada el 7 de abril de 1743 en San Lorenzo. ADB. San Lorenzo. Libro de bautismos. Legajo 1, folio 268. Era urgente canalizarlos hacia una actividad profesional que ellos mismos pudieran sufragar rápidamente con sus propios recursos y había que hacerlo cuanto antes mejor.

38 De entre la ingente cantidad de excelentes obras sobre el tema descuellan, a mi modesto entender, por su calidad y la luz que arrojan sobre la reconstrucción histórica COLLOMP, Alain: "Conflicts familiaux et groupes de residence en Haute-Provence", Annales ESC, 36-3, (1981), pp. 408-425 y "Tension, dissensions and ruptures inside the family in seventeenth and eighteenth-Century HauteProvence", MEDICK, Hans y SABEAN, D. W.: Interest and emotion. Essays on the study of family kinship, Cambrige, 1984, pp. 145170, VIEJO YHARRASSARRY, Julián: "Familia y conflictividad interpersonal en Guipúzcoa (Hernani, 1700-1750)", Estudios de Historia Social, 34-35, (1985), pp. 7-82, DAUMAS, Maurice: "Les conflicts familiaux dans les milieaux dominants au XVIIIe siècle", Annales ESC, 72-4, (1987), pp. 901-923, L'affaire d'Esclans. Les conflicts familiaux au XVIIIe siècle, París, 1988, y Le syndrome des Grieux. La relation père/fils au XVIIIe siècle, París, 1990, RODRÍGUEZ SÁNCHEZ, Ángel: "El poder familiar: la patria potestad en el Antiguo Régimen", Chronica Nova, 18, (1990), pp. 365-380. 
en el presente y en el futuro de los hijos, de los hermanos, de los sobrinos, ocasiona serios problemas de liquidez y, a la larga, graves distorsiones en el grado de aceptación de los resultados obtenidos.

\section{La compraventa de patentes militares: el porvenir a golpe de "talonario"}

Don Gaspar no era un hombre dado a las armas ni se le conoce ninguna vinculación directa con los Ejércitos Reales, con excepción de sus tratos con Dongo a cuenta de la adquisición de los empleos militares para sus hermanos. La tradición castrense era, sin embargo, en la familia una ocurrencia habitual, tanto en la rama paterna como en la materna. En primera instancia, su padre, don Francisco Antonio de Castro y Cárdenas, fue, además de "Gentil hombre de Cámara de Su Majestad", "Capitán de Granaderos del Reximientto de Infantería de Granada". Su abuelo, don Pedro de Castro y Cárdenas, "Coronel del rreximiento expresado de Granada" 39 y el bisabuelo, don Manuel de Castro, "Sargento Jral de Vatallas de los ejércitos de Su Majestad" ". En el derrotero paterno descuella también la figura de don Gaspar de la Torre Ayala, su tío-abuelo, hermano de doña Gabriela de la Torre, su abuela, quien alcanzó el grado de "Brigadier de los Ejércitos de S. M, Gentil hombre de Cámara de Su Majestad, Gobernador y Capittán general de las Islas Philipinas y Presidente de su Real Audienzia" mayor influencia benéfica, casi salvífica, ejerció sobre el hogar de los marqueses de Lorca. Al derramar sobre el padre de don Gaspar, merced a las cláusulas de su testamento, una monumental cantidad de activos financieros -"ocho mill diez y nueve Pesos y siette rrs de platta fuerttes" una notoria carencia de medios económicos y les permitió implicarse en empresas de alto calado -entre ellas la compra de patentes militares $-{ }^{43}$.

Entre los ascendientes de su madre, doña Josefa Manuela Gutiérrez de Salamanca, también se localiza un "Capitán de Carabineros en el Reximiento de Caballería Estremadura Viejo", don Ramón Gutiérrez Bocanegra y Girón, señor de Báscones del Agua, alcalde mayor perpetuo de ella, "Paje de Carlos II y Felipe V" y cofrade de la cofradía de los 13 caballeros hijosdalgo ${ }^{44}$. Empero, el árbol

\footnotetext{
39 ¿Qué mecanismos institucionales y/o castrenses emplearon los marqueses de Lorca para alcanzar sus empleos militares? Lo más probable es que fuera el levantamiento de Regimientos para el Rey, Felipe V, a su costa, es decir, el asiento militar como negocio y fórmula de adquisición de grado de mando. Véase BORREGUERO BELTRÁN, Cristina: "Del Tercio al Regimiento", Estudis, 27, (2001), pp. 53-89 y TORRES SÁNCHEZ, Rafael: ““'Servir al rey”, más una comisión. El fortalecimiento de los asentistas en la corona española durante la segunda mitad del siglo XVIII", FERNÁNDEZ ALBALADEJO, Pablo (Coord.): Monarquía, Imperio y pueblos en la España Moderna, Actas de la IV Reunión Científica de la AEHM, Alicante, 1997, pp. 149-167. Las referencias a sus quehaceres castrenses y cortesanos en, por ejemplo, AHPB. PN. Francisco de Villafranca. Legajo 7094 (5 de noviembre de 1761), folio 754. Poder del marqués de Lorca para urgir al cobro de sus "sueldos" como capitán y coronel en el Regimiento de Infantería de Granada. Véase ANGULO MORALES, Alberto: "Las escrituras de poder en el siglo XVIII. Un medio de sustitución y representación de las personas físicas y jurídicas", PORRES MARIJUÁN, Rosario (Dir.): Aproximación metodológica a los protocolos notariales de Álava (Edad Moderna), Bilbao, 1996, pp. 221-248.

${ }_{40}$ Un excelente resumen prosopográfico de las líneas de parentesco en AHPB. PN. Diego Fernández de Cormenzana. Legajo 7077 (22 de febrero de 1739), folios 55-59 - "Capitulaciones Matrimoniales entre Dn Francisco Castro y d Josepha Gutiérrez".

41 Véase, por ejemplo, AHPB. PN. Diego Fernández Cormenzana. Legajo 7082 (6 de septiembre de 1755), folios 123-128.

42 En realidad, la cantidad total entregada al II marqués de Lorca fue de 40.000 pesos de a 15 reales, de forma que los "Legados deel Señor dn Gaspar de la Torre" ascendieron a 1.020 .000 reales.

${ }_{43} \mathrm{Al}$ fallecer sin descendencia era perentorio e imprescindible canalizar su notable patrimonio hacia alguno de sus parientes. A don Francisco Antonio de Castro la riada monetaria del hermano de su madre le permitió salir de la pobreza y efectuar inversiones muy productivas Tal y como se describe en sus últimas voluntades, el II marqués de Lorca señaló que la "cantidad de quarenta mil pesos [que] tengo rezivida (...) con su Ymporte, cumpliendo con la Voluntad deel citado mi Tío [don Gaspar de la Torre, hermano de su madre] conpré a la Villa de Sta María de el Campo y me vendió en virtud de Real Facultad el término redondo y granja que llaman de Notoria de Riofranco con dos casas de Molinos y cinco ruedas para moler...". Además se hizo propietario de 3 casas con sus pajares, un monte, prados, 260 fanegas de sembradura y una iglesia parroquial. La compra se produjo el 16 de febrero de 1753 y se abonaron 262.000 reales de vellón. La orden testamentaria de don Gabriel era que "se empleasen en hacienda Raíz u otros efectos que Redituasen". Como veremos, estas propiedades generaron múltiples problemáticas al marquesado de Lorca. AHPB. PN. Diego Fernández de Cormenzana. Legajo 7082 (6 de septiembre de 1755), folios 124-125 y Francisco de Villafranca. Legajo 7095 (2 de febrero de 1763), folio 263.

${ }_{44}$ AHPB. PN. Diego Fernández de Cormenzana. Legajo 7077 (22 de febrero de 1739), folio 55. Para éste y otros empleos cortesanos, véase ÁLVAREZ-OSORIO ALVARIÑO, Antonio: "El arte de medrar en La Corte: Rey, nobleza y el código de honor", CHACÓN JIMÉNEZ, Francisco y HERNÁNDEZ FRANCO, Juan (Eds.): Familia, poderosos y oligarquías, Murcia, 2001, pp. 39-60, GÓMEZCENTURIÓN JIMÉNEZ, Carlos María: "Etiqueta ceremonial palatino durante el reinado de Felipe V: el reglamento de entradas de 1709
} 
genealógico materno basculaba más hacia los menesteres de la Corte -el padre del citado don Ramón, es decir, don Pedro Gutiérrez y Girón, fue "Gentil Hombre de la Voca de Su majestad" como alcalde mayor perpetuo de Burgos, que era, a la postre, el empleo prioritario en esa deriva familiar. De hecho, don Gaspar contrajo nupcias con doña Manuela de Salamanca, cuyo padre, don Fernando de Salamanca y Aguilar ${ }^{46}$.

Su hijo, don Joaquín Francisco, fue enlazado, empero, con una de las hijas de don José Antonio de Horcasitas, Comisario ordenador de los Reales Ejércitos, Intendente general de la provincia de Burgos y Corregidor en su capital por nombramiento de Su Majestad. El padre de don José Antonio ocupó plaza en el Real Consejo de Hacienda y ejerció como "Tesorero Gral de la Guerra" ${ }^{47}$. La progenie de don Gaspar retornó a la tradición militar, actividad a la que él fue totalmente remiso e incluso refractario. Su incesante búsqueda de inversiones y de un control exhaustivo en la administración de sus mayorazgos le enervaban, pero eran imprescindibles para mantener su rango y nivel de vida. Las actividades que a él le inquietaban, le daban plenitud y alegría vital, eran las vinculadas al Consulado de Burgos ${ }^{48}$ y a la "Real Academia de la Historia"49. Su leitmotiv eran las letras, disparar con la palabra, escribir con la bayoneta afilada del cálamo y el tintero, idear estrategias pacificas de modernización y de progreso ${ }^{50}$. El III marqués de Lorca era un hombre educado, culto y tranquilo, poco amigo del agua bendita y las sacristías y mucho menos de la pólvora y los patios de $\operatorname{armas}^{51}$.

y el acceso a la persona del Rey", Hispania, 914, (1996), pp. 965-1005, “Al cuidado del cuerpo del Rey: Los sumiller de corps en el siglo XVIII”, Cuadernos de Historia Moderna, anejo II, (2003), pp. 199-239, ELÍAS, Norberto: La sociedad cortesana, Méjico, 1982.

45 Ibídem, folio 55. No está de más indicar, a mi modesto entender, que para todo este sesgo cortesano es imprescindible revisar IMÍZCOZ BEUNZA, José María: “Actores sociales y redes de relaciones en las sociedades del Antiguo Régimen. Propuestas de análisis en Historia social y política", BARROS, C.: Historia a debate, tomo II, Santiago de Compostela, 1995, pp. 341-353, Élites, poder y red social. Las élites del País Vasco y Navarra en la Edad Moderna, Bilbao, 1996, Redes familiares y patronazgo. Aproximación al entramado social del País Vasco y Navarra en el Antiguo Régimen (siglos XV-XIX), Bilbao, 2001, PORRES MARIJUÁN, Rosario: Aproximación metodológica a los protocolos notariales de Álava (Edad Moderna), Bilbao, 1996, CASTELLANO, Juan Luis y DEDIEU, Jean Paul (Dirs.): Réseaux, familles et pouvoirs dans le monde ibérique à la fin de l'Ancien Régime, París, 1998 y MORALES MOYA, Antonio: "Movilidad social en la España del siglo XVIII: aspectos sociológicos y jurídicos de la concesión de títulos nobiliarios", Revista Internacional de Sociología, 62, (1984), pp. 463-489 y "Milicia y sociedad en el siglo XVIII", Cuadernos de Historia Moderna, 9, 1988), pp. 121-137.

46 Fue uno de los más activos regidores perpetuos del Concejo burgalés en el siglo XVIII. AHPB. PB. Francisco de Villafranca. Legajo 7095 (25 de mayo de 1762), folios 105-108 y ADPB. CE. Respuestas Particulares. Seglares. Libro 344, folios 996-1013.

47 AHPB. PN. Alonso de Melo Peña. Legajo 7221 (22 de noviembre de 1786), folios 536-541. Sobre los Horcasitas, véase BRAVO LOZANO, Jesús: "Don Francisco de Horcasitas. Las posibilidades de Madrid a fines del siglo XVII", Estudios de Historia Social, 36-37, (1986), pp. 497-521.

${ }_{48}$ Sobre su participación en el Consulado véase BALLESTEROS CABALLERO, Floriano: op. cit., 1983, MARTÍNEZ RUIZ, Enrique y GIL MUÑOZ, Margarita: "Signos burgueses en los militares españoles del siglo XVIII", ENCISO RECIO, Luis Miguel (Coord.): La burguesía española en la Edad Moderna, tomo II, Madrid, 1996, pp. 995-1008 y SANZ DE LA HIGUERA, Francisco: "Las Restauraciones del Consulado...", Historia, Instituciones, Documentos, 29, (2002), pp. 429-458, "Estando como estamos...", Boletín de la Institución Fernán González, 229, (2004), pp. 377-413 y "Aproximación a la locura en el Setecientos burgalés...", Investigaciones Históricas, 29, (2009).

49 A partir de mediados de la década de los 80, a don Gaspar le cabía un inmenso placer en titularse "individuo de la Real Maestranza de Granada y de la Real Academia de Historia de Madrid". Véase, por ejemplo, AHPB. PN. Alonso de Melo Peña. Legajo 7221 (22 de noviembre de 1786), folio 536. La coletilla de su prosopografía, títulos y posesiones concluía con los dos citados empleos, lo cual da un énfasis especial y descollante a su adscripción a dichas instituciones. Véase FRANCO RUBIO, Gloria: "Militares ilustrados y prácticas de sociabilidad", Revista de Historia Moderna, 22, (2004), pp. 369-402 VELASCO MORENO, Eva: La Real Academia de la Historia (1738-1792). Una institución de sociabilidad, Madrid, 2000, GALLAND-SÉGUELA, M.: "Archives militaires espagnoles et prosopographie", Mélanges de la Casa de Velázquez, 28-2, (1992), pp. 41-53 y FERNÁNDEZ DURO, Cesáreo: "Catálogo de los individuos de número de la Real Academia de la Historia, desde su creación en 1735 hasta la fecha (con los temas de sus discursos)", Boletín de la Real Academia de la Historia, 33, (1898), pp. 353-400.

50 Ese es, sin duda, el sentir de sus denodados quehaceres en el Consulado en lo tocante a la promoción y "el fomento y adelantamiento de la Agricultura, Fábricas, Comercio e Industria”. AHN. Consejos Suprimidos. Legajo 923/6 (1780-1785). Véase su intervención en la concesión de premios al desarrollo de "una Mesa de juego para quatro" en SANZ DE LA HIGUERA, Francisco: "Lugares para el ocio en el Burgos del XVIII. Una aproximación socio-económica”, Stvdia Historica, Historia Moderna, 27, (2005), pp. 289.

${ }^{51}$ No le interesaron nunca ni la gestión municipal (Concejo) ni los campos de batalla (Ejército) ni la Administración del Estado (Reales Consejos) ni el contubernio de La Corte ni el servicio Real. Tampoco se inclinaba mucho por lo clerical y, en efecto, a ninguno de sus hermanos se le derivó hacia la carrera eclesiástica. Véase AGO, Renata: "Destin des cadets et carrière ecllésiastique dans la noblesse italienne du XVIIe siècle”, RAVIS-GIORDANI, Georges y SEGALEN, Martine (Dirs.): Les cadets, París, 1994, pp. 231-239 y CANDAU CHACÓN, María Luisa: La carrera eclesiástica en el siglo XVIII, Sevilla, 1993. 
Empero, aunque lo militar no le atraía - quizá incluso le disgustaba -, don Gaspar de Castro, marqués de Lorca, "Curador adbona" de sus hermanos menores, "deseando dar Carrera a los Expresados mis hermanos conforme a su Ilusttre Calidad y Inclinándose, a Imitación de sus antecesores, a Servir a S. M. en el Ejercicio de las Armas" señalaba, en enero de 1766, que había "solicitado por varios medios a Empleo y con efecto pude lograr con dn Carlos Manuel Dongo, que se alla levantando un regimiento a sus Espensas de Infantería, con la denominación de La Princesa, la gracia de una Compañía para el referido dn Francisco, mi hermano, estimada en Seis mill pesos de a quinze rreales, y una tenencia al nominado don Antonio en tres mil y quinientos, que uno y ottro compone la Cantidad de Ciento quarentta y dos mill y Quinientos rreales vellón" ${ }^{2}$. Para don Pedro, el menor de vástagos de su padre, indicó, en agosto de 1766, que -“deseando dar la correspondiente Carrera al referido"- había "solicitado que por S. M. se le confiera la plaza en el Real Colejio Militar de Caballeros Cadetes deel Real Cuerpo de Artilleros, de que está hecha la grazia" ${ }^{33}$.

A mediados de 1763, don Gaspar asume, de manera oficial, la tarea, encomendada por su padre, de actuar como "tutor de las personas y Vienes de dn Antonio, dn Ramón y dn Pedro de Castro Gutiérrez, Torres y Cárdenas (...) todos tres menores de Catozze años (...) y de dn Francisco (...) maior de Catorce años procurando su educación y Crianza Conforme a su Calidad"54. Fue un quehacer de envergadura, teniendo en cuenta "no haver Cumplido este los Veintte y Cinco años, no obstantte haver tomado esttado de Mattrimonio" 55 . En todo caso, "attendidas sus Zircunsttanzias, apttittud y Capacidad", el recién estrenado marqués, "dándose por su partte fianza lega, llana y abonada", ejercerá la "dha Tuttela y Curaduría, Rejirá, gobernará y Administtrará a dhos sus hermanos menores y sus vienes y dará Quentta con pago de ellos, sus frutos y rentas siempre que le sea pedido y mandado"56 con denuedo y aplicación.

A los 18 años de edad, recién casado y con un crecido hogar que administrar y controlar, don Gaspar, "aunque sea menor", se va a enfrentar al quehacer de "attender principalmente a dar a dhos mis Hermanos la educación y Carrera Correspondientte a su Calidad y al Recobro de los Crédittos por Deudas y Papeles que les esttán adjudicados (...) mantteniendo el Caudal en Dinero de dhos mis Hermanos en el Depósitto donde se alla". De los réditos y rentas de sus patrimonios procedería "la manutención y vestuario (...) y demás gasttos" ${ }^{\circ 7}$.

¿Con qué capitales contaban los marqueses de Lorca? ${ }^{58}$ En las "Capitulaciones Matrimoniales" de don Francisco Antonio de Castro con doña Josefa Gutiérrez se estableció que él mandaba "en arras y donación propternupcias para más aumento de su dote" 2.000 ducados "que confiesa Caven en la décima Parte de sus Vienes" $"$. Ella contaba, además, con 5.860 reales que por cuenta de sus legítimas paterna y materna le tocaban de sus progenitores y 42.964 reales de "dádivas que le han hecho diferentes Personas" ${ }^{\prime \prime}$. La que iba a ser su suegra le mandó "en atención a el cariño, amor y Voluntad que le tiene

\footnotetext{
52 AHPB. PN. Francisco de Villafranca. Legajo 7097 (31 de enero de 1766), folio 17.

Ibídem (26 de agosto de 1766), folios 190-195.

4 Ibídem. Legajo 7095 (2 de febrero de 1763), folio 264.

55 Recordemos que don Gaspar había nacido en abril de 1744 y se le entrega la tutela de sus hermanos menores en mayo de 1763. Contrajo matrimonio en mayo de 1762.

56 AHPB. PN. Francisco de Villafranca. Legajo 7095 (26 de mayo de 1763), folios 637-640, (22 de junio de 1763 ), folio 641 , (12 de octubre de 1763), folios 633-636 y (14 de agosto de 1764), folios 647-649. “... Administrará sus Vienes, Arrendando los Raízes y Imponiendo los que no lo fueren en fincas Seguras, percivirá y cobrará sus frutos y rentas, llebando de ttodo Libro de quentta y razón".

57 Ibídem, (26 de mayo de 1763), folios 638-639.

58 Las capitulaciones matrimoniales, las cartas de dote y arras y los inventarios post-mortem y los testamentos recopilados permiten evaluar, aunque sea de forma somera, el nivel de fortuna, y el ciclo evolutivo familiar, de los Castro y el impacto económico de los matrimonios celebrados.

59 AHPB. PN. Diego Fernández de Cormenzana. Legajo 7077 (22 de febrero de 1739), folios 55-59 y (5 de mayo de 1739), folios 121-127, "Carta de Arras". Véase GIL MUÑóZ, Margarita: "Aproximación al estudio de la vida familiar de los militares españoles (siglo XVIII)", Revista de Historia Militar, 96, (2004), pp. 99-145.

60 En especial de Doña María Gabriela, cónyuge de don Pedro de Castro, Ier Marqués de Lorca -título concedido por Felipe V el 14 de marzo de 1712, sobre tierras de Sicilia y anotado en los privilegios del reino de Nápoles. Don Pedro nació en Chefalu (Sicilia)-, vivía acogida por su hijo en el hogar de la calle San Lorenzo. Era originaria de Flandes. ADPB. CM . Respuestas Particulares. Seglares. Libro 344, folios 943-949.
} 
a dha Sra $D^{a}$ Josepha Manuela" múltiples alhajas, cargadas de oro, diamantes y rubíes ${ }^{61}$. A ello se une la vivienda que don Ramón Gutiérrez y doña Francisca María de Salamanca habían puesto a disposición de la pareja en la calle San Lorenzo ${ }^{62}$. Al fallecer, en 1763, las "Quentas y Particiones" que se efectúan sobre los bienes de don Francisco Antonio nos ofrecen un "Cuerpo de Hazienda" nos deparan un cómputo total de 1.729 .760 reales $^{63}$. En los últimos meses de su existencia intentó solucionar, de manera ardiente y compulsiva, los problemas económicos que le acuciaban para que sus hijos no sufrieran una merma excesiva en su nivel de vida ${ }^{64}$.

En los hogares de los marqueses de Lorca, como en otros muchos en el Antiguo Régimen, se tenía la costumbre, solidaria pero también interesada, de albergar a familiares huérfanos o con graves problemas económicos en origen. Don Francisco Antonio, en su testamento de 1755, indica "traje a mi casa y Compañía y la he tenido y tengo a $D^{a}$ María Agustina Revilla de la Torre, mi Prima, y al mismo tpo rezivi y me entregó barias alajas suias propias que existen en dha mi casa y resultan de memoria que obra en mi poder, y a la expresada la he mantenido de todo lo preciso y necesario así de bestuario como para su manutención y gastado y suplido algunas cantidades de mrs para traerla de la Ciudad de Zaragoza, donde estava, y en el seguimiento de barios Pleitos suios, y por la referida me está hecha donación de todos sus Vienes y hacienda con la calidad de mantenerla durante los días de su vida" ${ }^{\circ}$. Doña María Agustina es retratada, junto al resto del hogar, en el Catastro de Ensenada ${ }^{66}$. Será enterrada el 4 de agosto de $1761^{67}$. Don Gaspar conocía, por lo tanto, la experiencia cercana de corresidir con una pariente, con las luces y las sombras que ello supone.

Don Gaspar de Castro contrajo matrimonio en 1762 con Manuela de Salamanca, Elio y Aguilar, hija de uno de los más "Ilustres" regidores perpetuos del Concejo burgalés, don Fernando de Salamanca. Las "Capitulaciones Matrimoniales" se rubricaron en mayo de 1762. Don Francisco Antonio, II marqués de Lorca, fallecía en febrero de $1763^{68}$. Don Gaspar fue "dispensado por su Santidad del parentesco de Segundo con terzero grado de Consanguinidad que media entre dhos Señores", dado que eran primos carnales ${ }^{69}$. Don Gaspar dotó en arras y donación con "Quatro mill Ducados de Vellón que Confiesa tienen

${ }_{61}$ AHPB. PN. Diego Fernández de Cormenzana. Legajo 7077 (22 de febrero de 1739), folio 58 -“Capitulaziones Matrimoniales"- y (5 de mayo de 1739), folios 122-125- "Carta de Arras" -. Descuella "Un par de Manillas de Alcofar y un collar de lo mismo Granadas Orientales que pesan dhas Manillas y Collar Siete Honzas y Seis Ochavas, que dhas Manillas tienen mill Ziento y quarenta y dos Granos, y el Collar Ziento y treinta, y todo ello, según su calidad y limpieza Hace Veinte y dos mill reales Vellón". Doña María Gabriela falleció el 23 de enero de 1755. ADB. Nuestra Señora de Viejarrúa. Libro de difuntos. Legajo 1, folio 27.

62 "... y por los días de la Vida de dho Señor Dn Ramón Gutiérrez los quartos Vajos de la Casa en que al Presente Viven a la calle de San Lorenzo y que lo Haze en ellos dho Señor Marqués en compañía de la Señora Marquesa Su Madre, Para que lo ejecute en la misma forma todo el dho tiempo la expresada Señora su Hija en compañía deel Zitado Señor Dn francisco, O los Arrienden, aprovechándose de su renta, que an dado por ellos asta quinientos reales Vellón en cada un Año (...) y en caso de que por algún motivo dho Señor Dn Ramón necesitase de los expresados quartos, llegado este caso le mandan a dha Señora Su Hija en la misma forma que lo llevan echo de dhos quartos la casa Grande que pertenece a sus Mayorazgos a la Calle de los Avellanos". AHPB. PN. Diego Fernández de Cormenzana. Legajo 7077 (22 de febrero de 1739), folio 57.

${ }_{63}$ El 58.9 \% de dicho patrimonio, 1.020 .000 reales, procedía del "Legado deel Sor dn Gaspar de la Torre", su tío, hermano de doña Gabriela. A cada hijo - efectuadas las detracciones imprescindibles (deudas en contra, funeral, gastos judiciales, "Gasto de la casa", reparos en las propiedades, etc.) - le tocaba a 85.810 reales. AHPB. PN. Francisco de Villafranca. Legajo 7095 (30 de agosto de 1763), folio 585. Al primogénito, la titularidad, además, de los mayorazgos.

${ }_{64}$ Sobre el cobro de atrasos en los "sueldos" militares, AHPB. PN. Francisco de Villafranca. Legajo 7094 (5 de noviembre de 1761), folio 751 y (20 de marzo de 1762), folio 73. Sobre la percepción de herencias, AHPB. PN. Francisco de Villafranca. Legajo 7095 (8 de enero de 1762), folio 15 y (6 de julio de 1762), folio 135. La gestión de sus mayorazgos en AHPP. PN. Francisco de Villafranca. Legajo 7095 (12 de noviembre de 1762), folios 206-207.

${ }_{65}$ "... y en caso de que subsista en ello y se quiera conformar, Dn Manuel Estevan de Castro, mi hijo maior, lo podrá hazer a quien se le entreguen en este caso todos los referidos Vienes y de no a la susodha pagando todos los alimentos y demás gastos que he tenido y suplido". Además, el III marqués de Lorca cobró, por mandato de don Gaspar de la Torre, "una Pensión que pertenecía a la citada $D^{a}$ María Agustina [de] cinquenta mil rrs de Vellón en dinero efectibo, cuia cantidad no se le ha entregado". Era su voluntad que "en caso de que los pida se le satisfagan de los primeros Caudales que sean de Indias, de la herencia de dho Señor Dn Gaspar". AHPB. PN. Diego Fernández de Cormenzana. Legajo 7082 (6 de septiembre de 1755), folio 126.

${ }_{66}$ ADPB. CM. Respuestas Particulares. Seglares. Libro 344, folios 943-949.

67 ADB. San Lorenzo. Libro de difuntos. Legajo 1 (4 de agosto de 1761), folios 121-122.

68 ADB. San Lorenzo. Libro de difuntos. Legajo 1 (12 de febrero de 1763). Doña Josefa Manuela Gutiérrez, su cónyuge, había fallecido el 13 de enero de 1754 y así quedó anotado en ADB. San Lorenzo. Libro de difuntos y Nuestra Señora de Viejarrúa. Libro de difuntos, folio 96 .

69 AHPB. PN. Francisco de Villafranca. Legajo 7095 (25 de mayo de 1762), folio 105. 
Cabimiento en la Décima parte de sus vienes que al presente posee" ${ }^{\text {"70 }}$. Don Francisco Antonio puso a su disposición, "en atenzión a Ser este tal su hijo maior Varón primo Jénito e inmediato subcesor a los Mayorazgos, Títulos y Patronatos que posee (...) [y al] especial Cariño, afecto y amor Paternal que le a tenido y tiene y a lo mucho que a deseado y desea Su Señoría se efectúe el Matrimonio"71. A ello se añadieron los 8.000 ducados que "para ayuda de mantener las Cargas [del matrimonio]" concedió don Diego María de Salamanca, hermano y curador de doña Manuela ${ }^{72}$. La pareja recién creada disponía, aproximadamente, al inicio de su convivencia conyugal de medio millón de reales de patrimonio.

Con las mieles del matrimonio aún en los labios, la convivencia con los hermanos -todos ellos varones- sería cuando menos problemática. La corresidencia duró poco. Don Gaspar nos comunica, en enero de 1766, que, "inclinándose a Imitación de sus antecesores a Servir a S. M. en el Ejercicio de las Armas ha solicitado por varios medios Empleo", ha conseguido, en efecto, a través de Dongo, una capitanía para Francisco, "estimada en Seis mil pesos de a quinze rreales" y una tenencia para Antonio "en tres mil y quinientos" $"$. La suma de ambas cantidades suponía un desembolso de 142.500 reales. Y aquí surge el gran problema, por que "no alcanzando a completarlos el líquido Dinero que de sus lejitimas tenían Existentes y perteneciéndoles la Sexta partte a cada uno de Diferentes vienes rraizes y otros efecttos libres y aloyales que dho Señor mi Padre Correspondía en la Ciudad de Bruselas, en los Esttados de flandes, por legítimos títulos, de que toca a cada uno Diez y Siette mill quarenta y ocho rreales y veintte y quatro mrs y medio"74.

Don Francisco y don Antonio únicamente disponían de 116.904 reales y 21 maravedíes, "faltándoles para completar el ymportte de dhas Patentes Veintte y Cinco mill quinientos noventa y cinco rs y treze mrs, además de los gastos de su equipaje y viaje al Puertto de Sta María (...) que uno y ottro llegará a Trescientos Doblones"75. El déficit se enjugaría con la percepción efectiva, en dinero contante y sonante, de sus legítimas y de la sexta parte de los 34.000 florines y 8 sueldos en que estaba tasada la hacienda libre de la familia en Flandes "por herencias de los Señores $D^{a}$ María Gabriela de la Torre y dn Gaspar de la Torre" ". Don Gaspar compró a sus hermanos los bienes citados ${ }^{77}$. El marqués de Lorca en ejercicio estaba muy receloso de que sus hermanos le increparan sobre la cuantía de dichas propiedades. Confesaba que "aunque en razón de vender dhas dos parttes de hacienda en nombre y como ttal Curador de dhos mis hermanos e hecho muchas diligencias no he podido allar quien más ni aún tanto por ellas me dé, y que no lo valen""78.

\footnotetext{
70 Ibídem, folio 106. Asimismo con "todos los Vienes, Dinero, Alajas, Joyas y demás que dha Señora Juntase a el Matrimonio".

71 El nuevo matrimonio "se mantendrá en su Casa y Compañía (...) teniéndoles a su mesa y asistiéndoles de todo lo necesario y con el bestuario Correspondiente a Su Clase y Calidad y en la misma forma a los hijos que tubieren (...) sin les faltase cosa alguna durante los días de dho Señor Marqués, y Interin permanezcan en dha Su Casa y Compañía, manteniendo Igualmente a Sus Criados necesarios a Su Asistencia y Servizio y pagará a éstos sus respectivos Salarios". Ibídem, folio 106.

72 El "Ilustre Señor Dn Diego María de Salamanca (...) Poseedor de los Maiorazgos de Su Casa y Apellidos y Curador de la misma Señora" ofreció entregar 8.000 ducados, 88.000 reales, "en esta forma, Sesenta mill Cinquenta y un Reales y veinte y Siete mrs que correspondieron a la nominada $D^{a}$ Manuela, Su hermana, por sus lexitimas en las quentas y Particiones que se hicieron de los vienes que quedaron por muerte de dhos SeñoresSus Padres - 12.197 1/2 reales en oro, plata y "pedrería" y 27.948 1/2 reales "adjudicados en dinero y omenaje de entre Casda" - y 27.948 reales y 7 maravedíes dados por don Diego María "para aumento de su Dote por el especial Afecto y Cariño que la ha tenido y tiene". AHPB. PN.

73 AHPB. PN. Francisco de Villafranca. Legajo 7097 (31 de enero de 1766), folio 15. La "Compañía" para Francisco, cifrada en 90.000 reales, suponía un desembolso de 30.000 reales por encima de lo que se pagaba en la Corte por el empleo de capitán. La tenencia para Antonio, 52.500 reales. Fueron abundantes las quejas de aristócratas de notable prosapia a la Corona y la administración borbónica por los gravámenes impuestos por Dongo. ANDUJAR CASTILLO, Francisco: El sonido del dinero..., Madrid, 2004, pp. $271-282$.

74 Don Gaspar se las hubo de ingeniar para recaudar el capital imprescindible para la inversión castrense. En las "Quentas y Particiones" de don Francisco Antonio, su padre, se les asignó "A los 6 restantes hijos a 85.810 reales y 2 mrs cada uno". Únicamente la venta de bienes raíces podía arreglar el déficit financiero de los aspirantes a militares. AHPB. PN. Francisco de Villafranca. Legajo 7095 (30 de agosto de 1763), folio 585.

75 AHPB. PN. Francisco de Villafranca. Legajo 7097 (31 de enero de 1766), folio 10.

76 Ibídem, folio 17.

77 "con todas las Entradas y salidas, Usos, Costumbres, regalías, derechos y Servidumbres (...) y con el goze de su renta (...) por prezio y quantía de treinta y quatro mil noventa y siette rreales y quinze mrs Vellón que Importan a los dhos Diez y siette mil quarenta y ocho rreales y Veintte y quattro mrs y medio en que les esttá adjudicada a cada uno". Ibídem, folio 10. La renta de dichas posesiones ascendía a un $3 \%$ "a corta diferencia, como resulta de las Dilijenzias de Imventtario Tasación y división practicadas".

78 “... y caso que aora o en algún tiempo más puedan Valer, de la ttal demasía ago Gracia y Donación a los Expresados dn Ramón y dn Pedro, buena, pura, mera, perfecta, acavada y rrenovable, que el derecho llama Intervivos para siempre Jamás". AHPN. PN. Francisco de Villafranca. Legajo 7097 (31 de enero de 1766), folio 16.
} 
A la postre, el montante de esta transacción, unido al "dinero detenido por falta de Empleo" que tenían los implicados, va a posibilitar las adquisiciones, las "Patentes", que tanta "nottoria Utilidad [que] a unos y otros se les seguía"79 y que no era otra que la obtención de un sueldo asegurado de forma vitalicia por las plazas militares, es decir, "una Decente manutención y los ascensos que son consiguientes a ellas" " "La Escasez de Empleos en estta Ciudad y sus cercanías, que es notoria, no ha permittido el poderse hazer en manera alguna" ${ }^{\text {11 }}$ con otro futuro que no fuese el de la almoneda militar. Dos hijos de la aristocracia parvenu de la ciudad de Burgos ${ }^{82}$ mutaron su residencia en una triste y anodina ciudad castellana ${ }^{83}$ por un pujante y efervescente enclave gaditano, El Puerto de Santa María $^{84}$, el problemático hogar de su hermano don Gaspar y su cuñada doña Manuela de Salamanca por el abigarramiento cuartelero ${ }^{85}$.

A mediados de 1774, el III marqués de Lorca nos describe, de una manera indirecta, y circunstancial, su agonía económica. La penuria en que se encuentra hace "forzoso para ocurrir a los indispensables gastos, manutención y acomodo" que se derivaban de haber atendido a sus hermanos menores y a su sobrino don Joaquín Santiago "balerme del favor de don Antonio de las Peña y Zelis, conde de Santibáñez, vecino de esta Ciudad, quien me ha franqueado considerable porción de dinero prestado, hallándome en el día con la obligación y precisión de devolverlo". Se encontraba con tal falta de liquidez que no le quedó otro remedio que "zederle dhos créditos ${ }^{86}$ para que cobrándolos sirvan para partte del pago de las dhas Cantidades que me tiene prestadas y en que esttamos Convenidos, vaxo de la Reserba de que no verificándose el recobro queda de mi cargo reintegrarle dha Cantidad en otros efectos" $" 87$.

Su postración material era una nimiedad si consideramos la desolación que generaban las ausencias de sus hermanos Francisco, Antonio y Pedro, en los que tanto tiempo y dinero había invertido. Existía, en la práctica, una pulsión contradictoria. Necesitaba sacárselos de encima con urgencia por razones económicas pero eran, al fin y a la postre, sus hermanos, carne de su carne, y su óbito o su mera ausencia producía un dramático dolor humano. En el documento en cuestión nos informa de que “don Francisco (...), capitán que fue del Reximiento de la Princesa, falleció en 29 de octubre de 1769 en la Granja de Hontoria de Riofranco, vajo la disposición testamentaria que hizo ante Dn Tomás de Mahamud, cura beneficiado en ella" y que "don Antonio (...), también mi hermano, primer theniente de la terzera Compañía del propio Reximiento de la Princesa falleció, en la ciudad de Valencia a 29 de noviembre de 1773, vajo la declaración testamentaria que otorgó en la Villa y Corte de Madrid en 10

\footnotetext{
79 AHPB. PN. Francisco de Villafranca. Legajo 7097 (31 de enero de 1766), folio 11. Véase ANDUJAR CASTILLO, Francisco: "La situación salarial de los militares en el siglo XVIII", BALAGUER i PERIGÜELL, Emilio y JIMÉNEZ LÓPEZ, Enrique (Eds.): Ejército, ciencia y sociedad en la España del Antiguo Régimen, Alicante, 1995, pp. 87-109.

${ }^{80} \quad$ Ibídem, folio 10. Véase ANDÚJAR CASTILLO, Francisco: ““'Aproximación al origen social de los militares en el siglo XVIII (1700-1724)", Chronica Nova, 10, (1979), pp. 5-31, Los militares en la España del siglo XVIII. Un estudio social, Granada, 1991 y El sonido del dinero..., Madrid, 2004.

${ }_{81}$ Ibídem, folio 11. De ello era testigo, en el doble sentido de la palabra, don Diego Alonso de Entenza, Varona y Rocaful, Marqués de Espinardo, gentilhombre de cámara del Rey, coronel de los Reales Ejércitos, Intendente y Corregidor de provincia y ciudad.

82 No olvidemos la reciente institución del marquesado de Lorca por Felipe V en 1712, al hilo de la Guerra de Sucesión. Entre los titulados de la ciudad no era, a pesar de los enlaces matrimoniales, uno de los más cercanos a sus mentalidades y prácticas aristocráticas.

${ }_{83}$ Véase, entre otros, CASADO ALONSO, Hilario y CAMARERO BULLÓN, Concepción: Burgos, 1751. Según las Respuestas Generales del Catastro de Ensenada, Madrid, 1994, CARASA SOTO, Pedro: Pauperismo y revolución burguesa. Burgos, 1750-1950, Valladolid, 1987 e IGLESIAS ROUCO, Lena Saladina: Arquitectura y urbanismo en Burgos bajo el Reformismo ilustrado (17471813), Burgos, 1978.

${ }^{84}$ IGLESIAS RODRÍGUEZ, Juan José: Una ciudad mercantil en el siglo XVIII. El Puerto de Santa María, Sevilla, 1991 y GONZÁLEZ BELTRÁN, Jesús Manuel: "Burguesía mercantil y gobierno municipal en la bahía gaditana. Los comerciantes portuenses del siglo XVIII. Su proyección en la política local”, ENCISO RECIO, Luis Miguel, op. cit., tomo II, Madrid, 1996, pp. 767-781.

85 El alejamiento de los hermanos menores era perentorio para todos.

86 Se trata de 3 créditos contra la Real Hacienda que dejó su padre, don Francisco Antonio, en la Contaduría General de Valores del Reino, más los sueldos, aún incobrados, de coronel y capitán de su abuelo y su padre y de su tío, don Francisco de Revilla, de quien se heredó el empleo de "Gentil hombre de Voca de la rreal Casa". AHPB. PN. Francisco de Villafranca. Legajo 7095 (8 de enero de 1762), folio 15, (20 de marzo de 1762), folio 73 y (5 de noviembre de 1761), folio 751.

${ }_{87}$ Las citas textuales de este párrafo en AHPB. PN. Julián Álvarez. Legajo 7264 (1 de junio de 1774), folios 146-147. En esa época, el conde de Santibáñez era su mano derecha, su poderhabiente, la persona de confianza en que se depositaba la gestión de sus intereses económicos.
} 
de octubre de $1773^{\prime 88}$. Se trata de una puntualización muy lacónica, tremendamente aséptica pero, a mi entender, demoledora e impactante ${ }^{89}$.

La deriva de don Francisco y don Antonio hacia El Puerto de Santa María se complementó con el envío de don Pedro hacia el mencionado Real Colegio Militar de Caballeros Cadetes del Real Cuerpo de Artillería ${ }^{90}$. En 1766 era imprescindible, para quienes deseaban integrarse en la milicia, acreditar "antes de la admisión su lexitimidad, nobleza, limpieza de sangre y de ofizios mecánicos" ${ }^{\prime 1}$. Tanto don Gaspar como los testigos que trajo a colación ${ }^{92}$ así lo indicaron ${ }^{93}$. En el oceánico volumen de los protocolos notariales de la ciudad de Burgos, únicamente en una ocasión más nos hemos tropezado con una "Información de legitimidad y limpieza de sangre (...) para entrar en el Real Seminario de Nobles de la Villa y Corte de Madrid" 94 . Corresponde al expediente presentado por don Miguel de Arriaga y Parisani, "Pretendiente" a dicha institución en 1758, hijo del teniente coronel don Miguel de Arriaga y Ribera ${ }^{95}$, hermano de don Cayetano de Arriaga ${ }^{96}$. A la aristocracia burgalesa no le interesaba excesivamente el derrotero castrense y en muy pocos hogares se detecta la presencia de alguno de sus componentes instalado en el mundillo castrense $^{97}$. A los problemas de entrada en las escuelas militares, siempre restrictivas, se unía el enorme coste económico que suponía su mantenimiento diario, el vestuario, los viajes, etc. ${ }^{98}$. La experiencia de los clérigos burgaleses tampoco era muy halagüeña ${ }^{99}$.

Don Gaspar vivía con un pie en Burgos y otro en Madrid ${ }^{100}$. Sus principales quehaceres se veían constantemente enturbiados y obstaculizados por los problemas derivados de la administración de

${ }_{88}$ Don Gaspar de Castro da cuenta de las luctuosas circunstancias en que se encuentra en AHPB. PN. Julián Álvarez. Legajo 7264 (1 de junio de 1774), folios 146-147.

89 Aunque no dispongo de confirmación documental, es presumible que ambos murieran solteros. Era usual, por tradición o como consecuencia de la legislación militar, que "la majorité des cadets de bonne famille n'a donc pas accès au mariage. Pour eux s'ouvrent plutôt les portes des carrières ecllésiastique ou militaire". AGO, Renata, op. cit. 1994) pp. 232.

yo Hidalguía, Índice de Expedientes Personales del Archivo General Militar de Segovia, tomo II (BÓ-CHY), (1959), Madrid, pp. 306.

91 AHPB. PN. Francisco de Villafranca. Legajo 7097 (26 de agosto de 1766), folio 190. Véase a este respecto los comentarios del profesor ANDUJAR CASTILLO, Francisco: Los militares en la España del siglo XVIII..., Madrid, 1991.

92 No eran, en absoluto, unos cualquiera sino algunos de los más preeminentes e ilustres aristócratas y gobernantes de la ciudad y su provincia. El más notorio de todos ellos era el Intendente y corregidor Marqués de Espinardo (don Diego Alonso de Enterra, Vera y Rocaful, Gentil hombre de cámara del Rey y coronel de sus Reales Ejércitos).

93 AHPB. PN. Francisco de Villafranca. Legajo 7097 (26 de agosto de 1766), folios 190-195. Su ascendencia era propia de "christianos Viejos, limpios de toda mala Raza de moros, Judios y penitenciados por el Santo oficio y de otra mala Secta reprobada, hijosdalgo notorios de Sangre según las leyes de Castilla, de la primera distinzión de esta Ciudad (...) [sin] haver exerzido ofizio vil alguno antes Si los más onoríficos y exerzitádose en el Servizio de las Armas"..

94 Ibídem. Legajo 7093 (18 de mayo de 1758), folios 460-466. Véase SOUBEYROUX, Jacques: "El Real Seminario de Nobles de Madrid y la formación de las élites en el siglo XVIII", Bulletin Hispanique, 97-1, (1995), pp. 201-212 y ANDUJAR CASTILLO, Francisco: Los militares en la España del siglo XVIII..., Granada, 1991 y El sonido del dinero..., Madrid, 2004.

95 Su testamento en AHPB. PN. Francisco de Villafranca. Legajo 7093 (6 de julio de 1757), folios 141-143. A la viuda Parisani le faltó escaso tiempo para sacar de casa a su hijo primogénito, embarazada como quedó de su cónyuge fallecido, "lo que no espresó dl dho dn Miguel, Mi Marido, por no haver estado advertido de ello".

96 ADPB. CE. Respuestas Particulares. Seglares. Libro 344, folios 526-540. Los testamentos de don Cayetano en AHPB. PN. Francisco de Villafranca. Legajo 6946 (17 de mayo de 1742), folios 52-53 y (23 de febrero de 1765), folios 113-120. Véase ABAD, Fabrice y OZANAM, Didier: Les intendans espagnols du XVIIIe siècle, Madrid, 1992, pp. 55-56.

${ }_{97}$ La Condesa de Murillo, doña Manuela de Vieira, viuda de Carvajal, tenía un hijo cadete guardiamarina. ADPB. CE. Respuestas Particulares. Seglares, Libro 344, folio 579. Pocos más hogares tienen militares oriundos de Burgos. Descuella don Miguel Antonio de la Torre, Ribera y Berna, noble rentista y coronel de Infantería Española. Imprescindible es la referencia a la saga encarnada en don Juan Manuel de Burgos y Jalón y su hijo don Juan Ibón de Burgos y Jalón. El primero ejerció como capitán y coronel del Regimiento de Milicias de Burgos y concluyó su vida militar como brigadier de los Reales Ejércitos y caballero de la Real Orden de Carlos III.

98 Así, por ejemplo, don José Fernández Vega, vecino de Burgos, se obligó con su persona, bienes y rentas, muebles y raíces, " $a$ contribuir con ocho rrs diarios a dn Antonio Ventura Anacleto, su Hijo, durante todo el tiempo que permanecerá de Cadete en el Regimiento de Infantería de Bruselas (..) y pueda con ellos atender a su manutención con la decencia y onor que se requiere...". AHPB. PN. Rafael Antonio Pérez. Legajo 7269/10 (10 de septiembre de 1787), s/f.

99 Uno de los hijos de don Ildefonso Río Pando, teniente de granaderos de milicias, se encontraba en casa, mantenido "desde hace tres años por encontrarse sin sueldo ni remuneración desde la retirada general de la tropa de Italia”. ADPB. Catastro. Memoriales, Libro 349, folio 348. Además en la vivienda se encontraban también otros dos hijos, Marcos Nicolás y Santiago, beneficiados en dos parroquias del entorno, quienes con sus escasos ingresos contribuían a su padre "en cuia casa vivo, para ayuda de mi manutención, que no pudiera ser sin esta unión". Ibídem, Libro 349, folio 479. Con un teniente agregado a la plana mayor se hallaba también en corresidencia, era su sobrino, el canónigo lectoral de la Catedral y rector del Seminario, don Manuel Antonio Prieto Bustamante. Ibídem, Libro 349, folio 461. La estrechez y la dependencia eran experiencias habituales. Cfr. SANZ DE LA HIGUERA, Francisco: "Clérigos a la sombra de un pariente en el XVIII burgalés", Hispania Sacra, 120, (2007), pp. 563-594 y MELENDRERAS GIMENO, María del Carmen: "Las campañas de Italia durante los años 1743-1748”, Murcia, 1987. 
sus propiedades y mayorazgos y la gestión cotidiana de su hogar. De entre los muchos imponderables que le acongojaban de manera habitual, descuellan los fraudes cometidos por su mayordomo en la granja de Hontoria de Riofranco ${ }^{101}$, los impagos de los renteros ${ }^{102}$ y los débitos relacionados con la adquisición de vestuario ${ }^{103}$. Solucionada la trayectoria profesional de sus hermanos, después hubo de enfrentarse, en 1787, al encarrilamiento del futuro de su propio hijo, don Joaquín Francisco, su único hijo y heredero. ¿Cuál era la trayectoria hacia la que dirigir a su heredero? ¿Qué aptitudes e intereses tenía don Joaquín?

En noviembre de 1786 fueron rubricadas las "Capitulaciones Matrimoniales entre los Sres dn Joaquín Francisco de Castro y Salamanca y da María Josefa de Horcasitas y Porras" ${ }^{104}$. Los marqueses de Lorca apostaban, en el amplio mercado nupcial, por el entronque con la genealogía del Intendente general de la Provincia y Corregidor de su Capital, don José Antonio de Horcasitas, caballero del orden de Calatrava y comisario ordenador de los Reales Ejércitos ${ }^{105}$. Lamentablemente, don Joaquín no especificó que cantidad concreta ofrecía "por aumento de Dote o en Arras y donación procter numpcias", capital que era, según lo usual, "la Décima parte en todos los Vienes y hacienda que tubiese y dejare al tpo de su fallecimiento"106. Don Gaspar, "por el mucho gusto y complacencia que en ello rezive, y para que se puedan mantener con el Lustre y decienzia correspondiente a su nacimiento (...) cede por razón de Alimentos todos los frutos y rentas de los quatro Mayorazgos que goza y posehe por los Apellidos de Gutiérrez, Bocanegra, Curiel y Polanco y en que subcedió por muerte del sor dn Gerónimo Gutiérrez $z^{107}$ (...) y los frutos y rentas sobre los frutos y rentas que se señalaren y sean equivalentes al pago del rédito anual que importare un Censo de ciento y cinquenta mill Reales de Pral", impuesto sobre los bienes del Mayorazgo fundado por don Gaspar de la Torre ${ }^{108}$. Don José Antonio de Horcasitas y su cónyuge "con igual deseo de que tenga efecto el Matrimonio para ayuda de levantar sus Cargas con la decienzia correspondiente" mandaron a la pareja "la Cantidad de Veinte mill Pesos de a quinze reales que hacen trescientos mill, los quales se han de entregar inmediatamente que se Celebre el Matrimonio" 109 . De ellos, "Los cinquenta o sesenta mill Rs han de servir para los gastos de Boda e importe de las Galas que se ejecutarán con

\footnotetext{
100 Muestra de ello lo encontramos en octubre de 1773 cuando doña Manuela de Salamanca, su cónyuge, advierte que don Gaspar, es vecino de Burgos pero "residente aquel en la Villa y Corte de Madrid". AHPB. PN. Rafael Pérez Romo. Legajo 7243 (17 de octubre de 1773), folios 78-79 y en Ibídem. Julián Álvarez. Legajo 7264 (14 de diciembre de 1774), folios 9-10.

101 AHPB. PN. Julián Álvarez. Legajo 7264 (1 de octubre de 1774), folio 22. El administrador al que se confió la "dirección y manejo del cultibo de su terreno, labranzas, Ganados y demás (...) ha omitido considerables porciones de Granos y mrs, minorando algunas y acrecentando excesivamente las de la Data". No se trataba de una nimiedad: 150.000 reales de sisa "en que me perjudicava en dhas quentas", afirmaba el marqués de Lorca.

${ }_{102}$ El devenir de la granja fue, en general, un auténtico suplicio. En 1774 se precisa expedir órdenes para cobrar las rentas de sus alquiladores de sus bienes raíces. En Quintanilla Somuñó, por ejemplo, se le adeudan 390 fanegas de centeno por la renta de un molino harinero. AHPB. PN. Julián Álvarez. Legajo 7264 (1 de febrero de 1776), folio 413. Finalmente, antes el cúmulo de incobrados y de problemas, don Gaspar decide arrendar la granja a don Antonio Tomé "para el Pasto y Rozo de los ganados de la Cabaña Merina transumante" por 9 años y 7.000 reales/año. AHPB. PN. Alonso de Melo Peña. Legajo 7222 (27 de julio de 1787), folios 340-344.

103 En diciembre de 1774, don Gaspar y doña Manuela se comprometen con Gaspar Pons, maestro sastre y vecino de Madrid, a liquidar una cuenta de 13.895 1 늘 reales que se le adeudaban por su trabajo del "tiempo de mi estancia en la Corte". Para ello, y durante 3 años, le entregarían 200 fanegas de pan por mitad, obtenidas en las rentas de sus mayorazgos. AHPB. PN. Julián Álvarez. Legajo 7264 (14 de diciembre de 1774), folios 9-10.

${ }_{104}$ AHPB. PN. Alonso de Melo. Legajo 7221 (22 de noviembre de 1786), folios 536-541 (Capitulación matrimonial) e Ibídem (15 de noviembre de 1787), folios 474-481 (Carta de dote).

${ }^{105}$ Las trayectorias familiares paternas se declinaron hacia lo militar y la Corte (Castro y de la Torre). Las maternas conectaban con la oligarquía urbana concejil de Burgos (Salamanca y Gutiérrez). Don Gaspar apostó por un nuevo sesgo, es decir, la intendencia, el corregimiento y los Consejos (Hacienda) (Horcasitas).

106 Ocurre en pocas ocasiones pero cuando sucede es síntoma inequívoco de una estrategia marcada por la ocultación de los parámetros económicos del contrayente. AHPB. PN. Alonso de Melo Peña. Legajo 7221 (22 de noviembre de 1786), folios 536-541.

107 Don Jerónimo Gutiérrez, marqués de Barriolucio, falleció en Pamplona en julio de 1774 "sin haver dexado hijos ni descendientes legítimos". Don Gaspar solicitó, en contra del parecer del su tío don Bernardo Gutiérrez, hermano del marqués y comendador en el Hospital del Rey (Burgos), el goce de los mayorazgos de la casa Gutiérrez, Girón y Bocanegra. AHPB. PN. Julián Álvarez. Legajo 7264 (16 de abril y 25 de junio de 1785), folios 281 y 306.

108 AHPB. PN. Francisco de Villafranca. Legajo 7098/1 (14 de noviembre de 1777), folios 362-376. La "Cesión y alargo de los Frutos de quatro Maiorazgos" a su hijo en AHPB. PN. Alonso de Melo Peña. Legajo 7222 (2 de octubre de 1787), folios 444-446.

109 AHPB. PN. Alonso de Melo Peña. Legajo 7221 (22 de noviembre de 1786), folios 739-740.
} 
arreglo a la lista que se acuerde entre los Padres de los Sres contrayentes" ${ }^{110}$. A los 300.000 reales citados, doña María Josefa añadía otros 35.627 reales de "dádivas y regalos que la hizieron diferentes Parientes y otras Personas" 111 .

El enlace de los Castro con los Horcasitas denota una deriva traumática en el estatus de los marqueses de Lorca. La ocultación, a mi entender deliberada y calculada, de cuál era el patrimonio de don Joaquín y las hipotecas en que se comprometen los mayorazgos de don Gaspar patentizan, a mi juicio, la existencia de un sesgo asimétrico entre los contrayentes. El III marqués de Lorca quedaba, en la práctica, convertido en cliente de los Horcasitas, endeudado hasta las cejas y debilitado notablemente su patrimonio ${ }^{112}$. Lo que se ganaba en capacidad de influencia se perdía en independencia y nivel de fortuna. Su calidad de vida desmejoraba notablemente. No es de extrañar que don Gaspar de Castro acabara su existencia con un grave deterioro de orden psiquiátrico, "una verdadera y notoria demencia, con absoluto desorden del buen juicio y potencias que anteriormente ha gozado"113.

\section{Manuel Dongo o la mafia militar en las cloacas del estado borbónico}

Despuntaba el año 1766 y don Gaspar de Castro, III marqués de Lorca, reconocía estar en contacto con don Carlos Manuel Dongo para concluir una transacción económica que le permitía adquirir las "Patentes" de una compañía y una tenencia para dos de sus hermanos huérfanos. Las instrucciones del marqués de Esquilache para la conformación de dos regimientos de infantería, con los nombres de Princesa y Príncipe, habían emanado de San Ildefonso a mediados de septiembre de $1765^{114}$. Don Gaspar de Castro dio, pues, muestras de estar muy atento, y ojo avizor, a las posibilidades que el mercado de trabajo ofrecía para sus hermanos. Frente a las estrategias de los inspectores de Infantería, que pensaban encargar su composición a oficiales en activo en dicho cuerpo -con objeto de darles excelentes oportunidades para su "adelantamiento"-, el Secretario del Despacho de Guerra -con o sin la "voluntad del Rey"- era partidario de entregar tales responsabilidades -con excepción de los empleos de teniente coronel, sargento mayor y ayudantes- a asentistas, es decir, a empresarios inversores ${ }^{115}$. Esquilache convertía la ampliación de las fuerzas armadas, las levas, en un negocio en el que, sin coste alguno para la Hacienda pública, y lejos de lo que había sido tradicional hasta ese momento en el levantamiento de regimientos y batallones ${ }^{116}$. En plena "Edad de la almoneda", una parte del ejército se transformaba en una especie de "Carrefour social" 117 en el que la burguesía penetraba en el corazón de un cuerpo hasta

\footnotetext{
110 AHPB. PN. Alonso de Melo Peña. Legajo 7221 (22 de noviembre de 1786), folio 739-740 - Recordemos que el enlace de don Joaquín de la Vega, sobrino del marqués de Lorca, supuso aproximadamente 54.000 reales -. Quedaban bajo la tutela "por espacio de dos años, contados desde el día en que se celebre el Matrimonio, en el caso de que quieran vibir en su Compañía". Si no fuera así, se obligaban a contribuirles con 500 ducados al año.

111 AHPB. PN. Alonso de Melo Peña. Legajo 7222 (15 de noviembre de 1787), folio 478-479.

112 En AHPB. PN. "Censo en orden de Real Facultad, el Señor Marqués de Lorca al señor dn Joséf Antonio de Horcasitas y Su Muger". Alonso de Melo Peña. Legajo 7222 (14 de febrero de 1787), folios 63-72. El crédito hipotecario, sobre los mayorazgos fundados por don Gaspar de la Torre, tenía un principal de 150.000 reales, a $3 \%$ sus réditos anuales (4.500 reales/año). Este censo fue redimido en julio de 1816. Don Joaquín y doña María Josefa no tuvieron sucesión y al fallecer ella, señaló sus últimas voluntades que un tercio de sus bienes dotales serían para su cónyuge y que su heredera universal era su madre, doña Leocadia Ruiz de la Escalera. AHPB. PN. Lorenzo de Rueda. Legado 7222 (23 de enero de 1816), folio 481. Don Gaspar de castro, III Marqués de Lorca, se vio en la necesidad de escudriñar la viabilidad y sostenibilidad de su patrimonio. Era imprescindible recavar el cobro de todas las rentas y herencias, cualquiera fuera su origen y condición. Véase AHPP. PN. Alonso de Melo Peña. Legajo 7219 (3 de febrero de 1784), folio 49-50, Legajo 7222 (11 de febrero de 1787), folio 54 y (25 de mayo de 1787), folios 277-278.

113 AHPB. PN. Alonso de Melo Peña. Legajo 7226/1 (9 de febrero de 1792), folios48-54. Cfr. LÓPEZ GÓMEZ, José Manuel: "Razón y locura en el Burgos de la Ilustración...", Estudios de Historia y Arte..., Burgos, 2005, pp. 177-181.

114 ANDUJAR CASTILLO, Francisco: El sonido del dinero..., Madrid, 2004, pp. 262.

115 Individuos que se encargarían de vender las "patentes en blanco para llenarlas a su beneficio en sujetos de circunstancias correspondientes, a condición de que uno de los tres empleos en cada compañía ha de recaer precisamente en persona que esté sirviendo en el exército". AGS. Guerra Moderna. Supl. Legajo 540 (13 de septiembre de 1765).

116 Un capitalista emprendía, al mismo tiempo, la recluta de soldados y oficiales a cambio de mandar el nuevo regimiento y la venta de los despachos de la oficialidad a quien quisiera y pudiera abonar sus costes. Véase ANDUJAR CASTILLO, Francisco: "La privatización del reclutamiento en el siglo XVIII: el sistema de asientos", Stvdia Historica, Historia Moderna, 25, (2003), pp. 123-147 y El sonido del dinero,..., Madrid, 2004 y BORREGUERO BELTRÁN, Cristina: El reclutamiento militar por quintas en la España del siglo XVIII. Orígenes del servicio militar obligatorio, Valladolid, 1989 y “Del Tercio al Regimiento”, Estudis, 27, (2001), pp. 53-89.

117 ANDUJAR CASTILLO, Francisco: El sonido del dinero..., Madrid (2004), pp. 35.
} 
entonces exclusivamente nobiliar con su más preciada, principal y poderosa arma: el dinero puesto al servicio de la venalidad del honor y la promoción militar.

Carlos Manuel Dongo, capitán del regimiento de caballería de Borbón, sabía mucho de la adquisición de "patentes". Él mismo había conseguido el empleo que ostentaba en 1762 a través del "servicio" de financiar el coste de 40 hombres vestidos, armados y montados para la caballería ${ }^{118}$. A cambio de ello, su gratificado con su patente de capitán y con dos patentes más -una de teniente y otra de subteniente-, empleos que podía comercializar, de manera privada, a su libre albedrío. Esta experiencia en formar una compañía le dio alas para elevar la apuesta a la constitución de un regimiento ${ }^{119}$.

En la puja por el regimiento de la Princesa, concurrieron tres propuestas. En primera instancia, el conde de Villaseñor, que deseaba hacerse con un grado de coronel de dragones. Desistió pronto porque no le interesaba la infantería. En segundo término, el asentista Juan de Florensa, que pretendía colocar a uno de sus hijos como coronel del regimiento -servía en 1765 como subteniente del un regimiento recién creado, el de infantería ligera de Cataluña-. La tercera opción provenía del mencionado Dongo, por el que se había inclinado, desde el primer momento, el marqués de Esquilache ${ }^{120}$, razón por la que los otros dos aspirantes desistieron rápidamente en sus intenciones. El capitán del regimiento de Borbón asumió, por tanto, después de realizar las inversiones monetarias pertinentes, el grado y el sueldo de coronel del regimiento de La Princesa, acantonado en El Puerto de Santa María ${ }^{121}$.

Natural de la ciudad de Méjico -donde había nacido en 1731-, hijo de don Juan Esteban Dongo, "que lo fue de la de Sevilla"122, y de doña María Ana Martínez de la Serna y Urrea, oriunda de Méjico, desconocemos el origen de los capitales que le habían permitido, a los 31 años de edad, adquirir la capitanía del regimiento de Borbón y a los 34 el mando, como coronel, del de La Princesa. Su disponibilidad de dinero, y probablemente su labia y habilidades sociales, influyeron poderosamente en el marqués de Esquilache, hasta el punto de hacer inclinar la balanza a su favor. Ya en 1752, soltero, era residente en El Puerto de Santa María. Lamentablemente no significó cuáles eran sus quehaceres profesionales ni el volumen de su fortuna -"El estado de mi Caudal y bienes constará con Claridad y distinción de mis papeles y apuntaciones de que tiene bastante noticia el nominado Cacho de Brezedo" (...) por la mucha satisfacción que del susodho tengo"123 . El temor a que su "fallecimiento acaeciese en la Villa de Madrid, no estando en ella ninguno de los seis referidos" 124 nombró por uno de sus testamentarios a don José de Aguirre Acharán, caballero del orden de Santiago, miembro del Consejo de Su Majestad ${ }^{125}$.

Dongo se dedicó sin escrúpulos a rentabilizar las 58 patentes en blanco que le fueron entregadas en el Palacio Real el 2 de enero de $1766^{126}$. Los precios abusivos que señaló a su mercancía, tan atractiva, sin embargo, para los hijos de la burguesía y de la nobleza, generaron múltiples denuncias de los compradores. Un empleo de capitán se vendía directamente en la Corte, en 1766, por 60.000 reales. El coronel Dongo cobró por ese grado 90.000 reales ${ }^{127}$. Quizás con ello compensaba el regalo que le hizo

\footnotetext{
118 ANDUJAR CASTILLO, Francisco: op. cit, pp. 263.

119 El problema no era insoluble: únicamente había que ampliar las proporciones de la inversión, inflacionar la cuantía de los empleos y atraer a los golosos compradores. El marqués de Lorca fue uno de ellos. Y no le importó, al menos aparentemente, desprenderse de los capitales de sus hermanos para enriquecer a Dongo.

120 ANDUJAR CASTILLO, Francisco, op. cit., pp. 264-266.

121 ANDUJAR CASTILLO, Francisco, op. cit., pp. 263-264. Además, síntoma y muestra de su notable disponibilidad económica, adquirió, en 1760, un hábito de la orden de Santiago e intentó la compra de un empleo de general.

${ }_{122}$ Archivo Histórico Provincial de Cádiz (AHPC). Protocolos Notariales (PN). Matías Rodríguez. Cádiz. Legajo 4485 (2 de abril de 1752), folios 644-646 y El Puerto de Santa María. Legajo 814 (21 de agosto de 1798), folio 208.

123 AHPC. PN. Matías Rodríguez. Cádiz. Legajo 4485 (2 de abril de 1752), folio 645.

124 Sus testamentarios eran su primo don Joaquín Dongo, un presbítero, don Manuel Ignacio Beye, y don Fernando González de Collantes, vecinos de México, y don Juan Antonio Cacho de Brecedo, don Juan de Villanueva Pico y don Ignacio de Leaburu.

${ }^{125}$ AHPC. PN. Matías Rodríguez. Cádiz. Legajo 4485 (2 de abril de 1752), folio 645. No andaba escaso de contactos y amistades en La Corte.

126 ANDUJAR CASTILLO, Francisco: El sonido del dinero, Madrid, 2004, pp. 265.

127 En ese anzuelo picaron, por ejemplo, el marqués de Lorca, el marqués de Ovando, el marqués de Lozoya, los Andoanaegui, los Unamunzaga, ... "Para algunas casas nobiliarias la venta de empleos militares representaba la oportunidad de colocar a los segundones en un puesto fijo en el servicio Real, garantizar su futuro o acelerar el ritmo de su cursus honorum". ANDUJAR CASTILLO, Francisco: op. cit., 2004, pp. 267.
} 
a Esquilache, en cabeza de su paje, Domingo Elordui, de una tenencia, procedimiento con el que uno y otro festejaban la concesión a Dongo de la leva del regimiento de La Princesa ${ }^{128}$.

El perfil mayoritario de quienes accedieron a las ventas de empleos por parte de Dongo transita por familias vinculadas a la administración de la Hacienda Real, por una parte, y al mundo de los negocios y el comercio, por otra ${ }^{129}$. La irrupción de don Gaspar de Castro, marqués de Lorca, en esta almoneda militar es, a mi entender, un hecho aislado y atípico, y más si tenemos en cuenta la imprudencia del aristócrata pro-borbónico e ilustrado burgalés al consignar por escrito lo que era un secreto a voces, la venalidad de los empleos castrenses. Don Gaspar y sus hermanos no eran comerciantes, ni funcionarios de la administración pública, ni miembros de la oligarquía municipal de gobierno ${ }^{130}$. El coronel Dongo fue, merced a su habilidad negociadora y al superávit financiera obtenido por sus ventas, un ariete demoledor en el conflicto entre honor y dinero que inundaba todas las estructuras del Estado borbónico. En las instancias gubernamentales se respira satisfacción- "casi todo valía -parafraseo las excelente palabras del profesor Andujar Castillo- con tal de incrementar el número de efectivos del ejército sin coste inicial para la hacienda real" ${ }^{\prime 131}$. Los turbios entresijos, los disparados precios, la nula experiencia militar y la escasa calidad humana de los nuevos oficiales quedaron amnistiados por un Estado que mercadeaba con casi todo ${ }^{132}$.

Don Carlos Manuel Dongo manejaba mucho dinero, inmensas cantidades de capital. Tenía atrapados a los compradores de las "patentes" militares, a sus propios subordinados y a otros individuos que recurrían a él en busca de ayuda para sus problemas financieros. Un ejemplo de los agobios a que estaban sometidos quienes se encontraban bajo su mando lo encontramos en don José Fleming ${ }^{133}$, capitán de infantería del regimiento de La Princesa, deudor para con su coronel, Dongo, de 45.000 reales "o de la cantidad que resultase a su favor después de ajustadas y aprobadas las Quentas de mi Compañía de Hombres y Bestuarios, según el tenor de la Contrata que en esta razón tengo hecha y firmada con dho mi Coronel (...)"134.

Remedio "para mis urgencias" buscó en el coronel Dongo el regidor perpetuo de El Puerto de Santa María don Blas Gregorio de Cañas Trujillo, quien recibió, en febrero de 1766, 15.000 reales $^{135}$. Mal debían ir las cosas para el edil cuando en octubre, "haviéndose cumplido dho plazo sin haver podido hacer la satisfacción" del empréstito, Cañas recurría al subterfugio, angustioso, de estar convencido que Dongo le iba a conceder más tiempo ${ }^{136}$. Se granjeaba así una presencia en El Puerto de Santa María que excedía con mucho lo que pasaba puertas adentro de su cuartel. No se alejaría nunca más de esa ciudad $^{137}$.

128 ANDUJAR CASTILLO, Francisco: op. cit., 2004, pp. 267.

129 ANDUJAR CASTILLO, Francisco: op. cit., 2004, pp. 267-274.

130 Empero, confluían con todos ellos en el sentimiento y la necesidad de situar a sus hijos y hermanos en el Servicio Real a través de un mecanismo, de una puerta falsa, en las que los requisitos de acceso no eran nada rigurosos. Únicamente era necesario disponer de dinero en efectivo y, con ello, se saltaban de un plumazo la totalidad de los agotadores filtros necesarios, en tiempo y profesionalidad, para alcanzar los cordones de cadete o las charreteras de oficial.

131 ANDUJAR CASTILLO, Francisco: op. cit., 2004, pp. 262-282.

132 El Estado borbónico vendía cargos en los Ejércitos, en la Iglesia, en la Justicia, etc. Véase, entre otras, las reflexiones de GÓMEZ GONZÁLEZ, Inés: La justicia en almoneda. La venta de oficios en la Chancillería de Granada (1505-1834), Granada, 2000 y SANZ DE LA HIGUERA, Francisco: “Cebada, mulas, caballos, carruajes y habas. La Catedral de Burgos en el Setecientos”, Hispania Sacra, 116, (2005), pp. 559-588.

133 ANDUJAR CASTILLO, Francisco: El sonido del dinero..., Madrid, 2004, pp. 267-268 e IGLESIAS RODRÍGUEZ, Juan José: op. cit., Sevilla, 1991, pp. 406.

${ }_{134}$ Las cantidades serían satisfechas "a la llegada de la Flota que próximamente está esperando llegue del Reino de Nueba España". El capitán Fleming hipotecó "unas casas que tengo en la calle de las Cruces" como garantía de sus deudas con Dongo. AHPC. PN. Francisco Uruburu de Toro. El Puerto de Santa María. Notaría 2, Legajo 688 (30 de enero de 1767), folio 123.

135 Con la promesa de "devolverlos en el plazo de seis meses". AHPC. PN. Francisco Uruburu de Toro. El Puerto de Santa María. Notaría 2. Legajo 684 (17 de febrero de 1766), folio 70 y (29 de abril de 1766), folio 194.

136 AHPC. Francisco Uruburu de Toro. El Puerto de Santa María. Notaría 2. Legajo 684 (30 de octubre de 1766), folio 724. El pagaré quedó depositado en manos de Dongo.

${ }_{137}$ La trampa financiera de don Blas Gregorio con Dongo no fue la única. Don José de Imbluzqueta, vecino y síndico personero de El Puerto, le prestó 32.816 reales por 6 meses - AHPC. PN. Francisco Uruburu de Toro. El Puerto de Santa María. Notaría 2. Legajo 684 (31 de diciembre de 1766), folio 787 -. Don Guillermo Tirri, marqués de la Cañada, hizo lo propio por un montante cercano a los 60.000 reales - Ibídem, (27 de diciembre de 1766), folio 780. 
Don Carlos Dongo rubricó otro testamento, quizá el último de sus intensos días, el 21 de agosto de 1798, tan críptico en lo económico como el anterior de 1752. En este documento apostaba por su sobrino, don Joaquín Dongo Pro ${ }^{138}$, a quien nombraba junto con su hermana, doña María de los Dolores, vecinos de la Ciudad de Sevilla, herederos universales de sus bienes, derechos y acciones, "para que los hayan, lleven y hereden para sí por iguales partes (...) respecto a no tener, como en efecto no tengo, herederos forzosos que según derecho puedan y deban heredar"139.

\section{A modo de conclusión}

Si don Gaspar de Castro, marqués de Lorca, y sus hermanos hubieran dispuesto de capital en abundancia en 1766 como para abonar las "patentes" de capitán y teniente que les vendía el coronel Dongo, únicamente el recurso a Guerra Moderna en el Archivo General de Simancas posibilitaría saber de sus andanzas y tribulaciones en lo tocante al futuro profesional y financiero de unos y otros. El verse obligados a recavar el dinero que les faltaba aireó a la luz pública un fenómeno que, en ningún caso, debiera haberse escriturado abiertamente. Sea imprudencia manifiesta o instrumento pergeñado para una irónica denuncia, lo cierto es que el marqués de Lorca se fue de la lengua y rubricó un documento, a mi entender, excepcional y único. Como señala el profesor Andujar Castillo, "De no ser por la existencia de una deuda entre el coronel del regimiento, Carlos Manuel Dongo, y dos hermanos denominados como los Olivas, no hubiésemos conocido con detalle el mundo interior del negocio de la venta de "empleos militares" en la España de Carlos III"140.

\footnotetext{
138 Además de pariente cercano - era su primo -, don Joaquín era el hombre de confianza, uno de los albaceas y heredero de sus bienes. Él es el receptor de un "Poder" dado por el coronel Dongo "para cobrar las cantidades de dinero de plata y oro que se deben por personas residentes en la ciudad de Méjico”. AHPC. Juan Antonio Salgado. Cádiz. Notaría 25. Legajo 5761 (27 de junio de 1767), folios 661-662 y 667 .

139 Se moría Dongo en casi completa soledad a la edad de 67 años. En algún lugar de sus aposentos, sus cabezaleros encontrarían "una Memoria o Papel escrito y firmado de mi puño" en la que Dongo expresaba sus deseos con respecto a las "Cláusulas, mandas y Legajos profanos, píos o graciosos, Funeral, Misas y entierro y demás a él concernientes". Incluso in artículo mortis se amparó en la confidencialidad y en el hermetismo para proteger sus intimidades y nivel de fortuna. En su cabeza, su corazón y sus papeles se albergaban secretos que pondrían en serios aprietos a la monarquía española y a múltiples hogares de la geografía española y latinoamericana. Las citas textuales de este párrafo en AHPC. PN. Francisco Uruburu de Toro. El Puerto de Santa María. Notaría 2. Legajo 814 (21 de agosto de 1798), folios 208-210.

140 ANDUJAR CASTILLO, Francisco: El sonido del dinero..., Madrid, 2004, pp. 279-281.
} 
